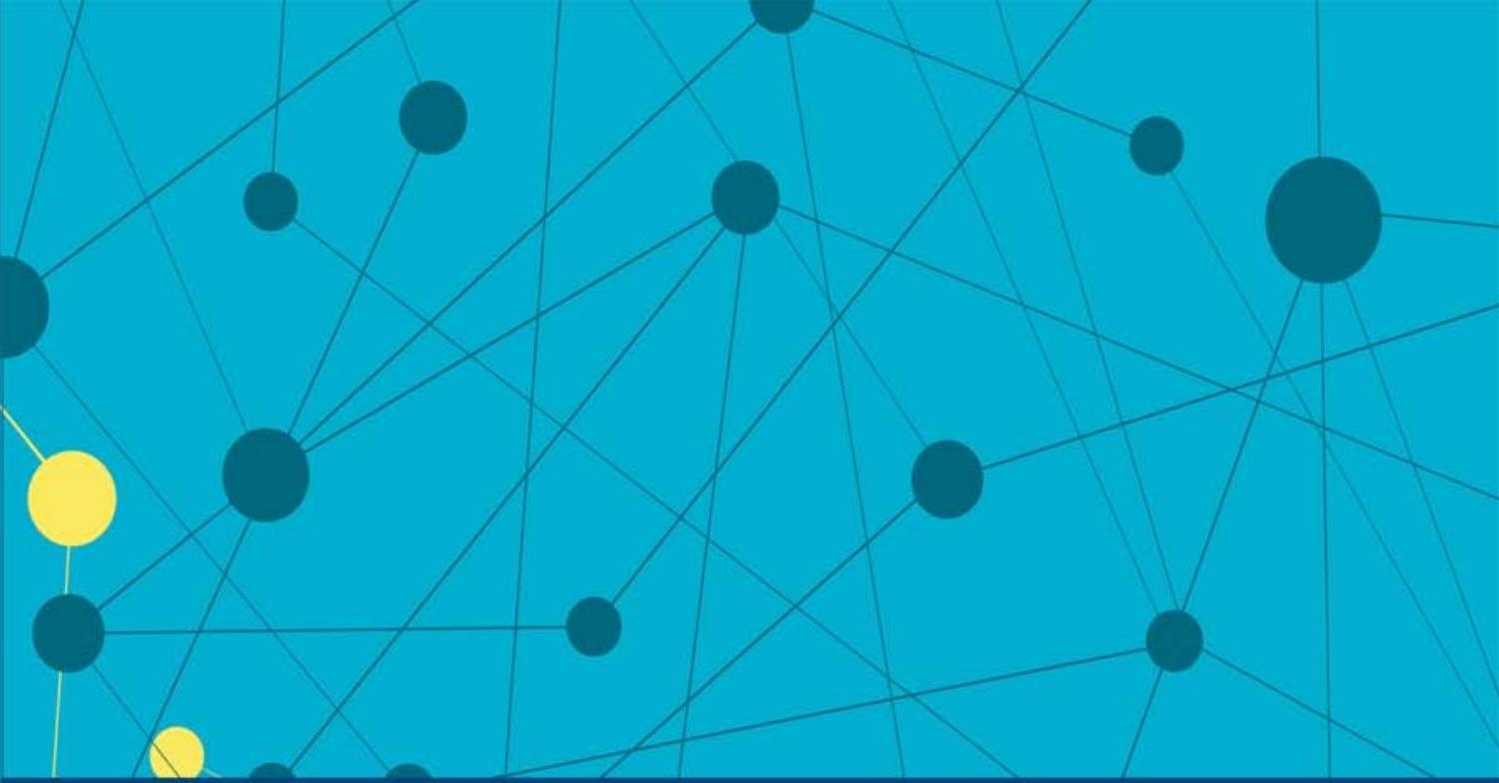

New Directions in Tourism Analysis

\title{
BEING AND DWELLING THROUGH TOURISM
} AN ANTHROPOLOGICAL PERSPECTIVE

Catherine Palmer

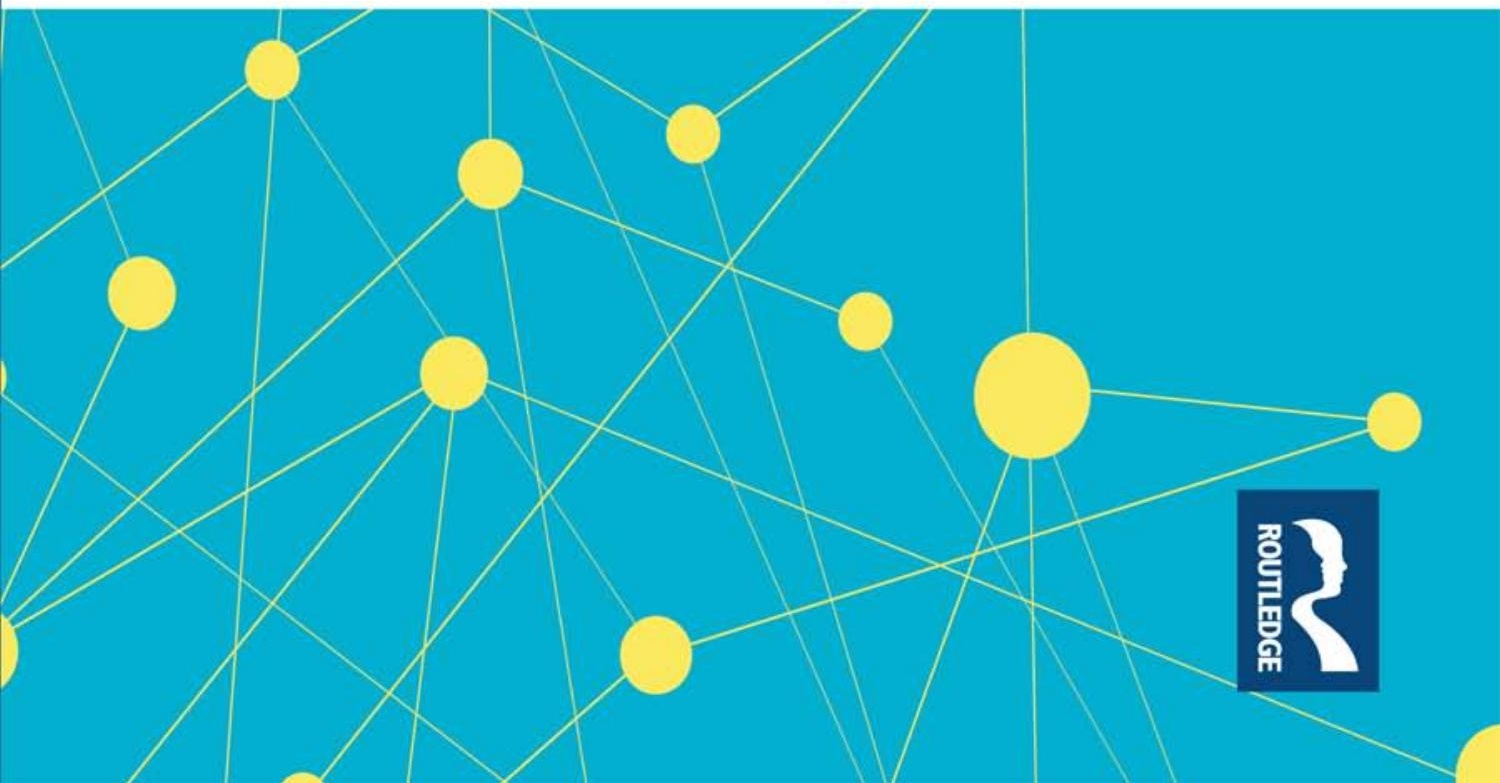




\section{Being and Dwelling through Tourism}

Much of the existing literature seeks to make sense of tourism based on singular approaches such as visuality, identity, mobility, performance and globalised consumption. What is missing, however, is an overarching framework within which these valuable approaches can be located. This book offers one such framework using the concept of dwelling taken from Heidegger and Ingold as the starting point from which to consider the interrelatedness of being, dwelling and tourism.

The anthropological focus at the core of the book is infused with multidisciplinary perspectives that draw on a variety of subjects including philosophy, material cultural studies and cultural geography. The main themes include sensuous, material, architectural and earthly dwelling and each chapter features a discussion of the unifying theoretical framework for each theme, followed by an illustrative focus on specific aspects of tourism.

This theoretically substantive book will be of interest to anyone involved with tourism research from a wide range of disciplines including anthropology, sociology, geography, cultural studies, leisure studies and tourist studies.

Catherine Palmer is a social anthropologist at the University of Brighton, UK. She is the joint book series editor for the Routledge Advances in Tourism Anthropology. Her publications and research interests encompass identity, heritage and materiality; post conflict/memorial landscapes; cultures of the coast/seaside; embodiment and the lived experience. 


\section{New Directions in Tourism Analysis \\ Series Editor: Dimitri Ioannides \\ E-TOUR, Mid Sweden University, Sweden}

For a full list of titles in this series, please visit www.routledge.com/NewDirections-in-Tourism-Analysis/book-series/ASHSER1207

Although tourism is becoming increasingly popular both as a taught subject and an area for empirical investigation, the theoretical underpinnings of many approaches have tended to be eclectic and somewhat underdeveloped. However, recent developments indicate that the field of tourism studies is beginning to develop in a more theoretically informed manner, but this has not yet been matched by current publications.

The aim of this series is to fill this gap with high quality monographs or edited collections that seek to develop tourism analysis at both theoretical and substantive levels using approaches which are broadly derived from allied social science disciplines such as Sociology, Social Anthropology, Human and Social Geography, and Cultural Studies. As tourism studies covers a wide range of activities and sub fields, certain areas such as Hospitality Management and Business, which are already well provided for, would be excluded. The series will therefore fill a gap in the current overall pattern of publication.

Suggested themes to be covered by the series, either singly or in combination, include: consumption; cultural change; development; gender; globalisation; political economy; social theory; and sustainability.

\section{Metropolitan Commuter Belt Tourism}

Edited by Michat Jacenty Sznajder

\section{Performing Cultural Tourism}

Communities, Tourists and Creative Practices

Edited by Susan Carson and Mark Pennings

43 Advances in Social Media for Travel, Tourism and Hospitality

New Perspectives, Practice and Cases

Edited by Marianna Sigala and Ulrike Gretzel

\section{Being and Dwelling through Tourism}

An Anthropological Perspective

Catherine Palmer 


\section{Being and Dwelling through Tourism \\ An Anthropological Perspective}

Catherine Palmer

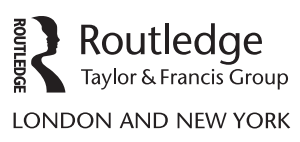


First published 2018

by Routledge

2 Park Square, Milton Park, Abingdon, Oxon OX14 4RN

and by Routledge

711 Third Avenue, New York, NY 10017

Routledge is an imprint of the Taylor \& Francis Group, an informa business

(C) 2018 Catherine Palmer

The right of Catherine Palmer to be identified as author of this work has been asserted by her in accordance with sections 77 and 78 of the Copyright, Designs and Patents Act 1988.

All rights reserved. No part of this book may be reprinted or reproduced or utilised in any form or by any electronic, mechanical, or other means, now known or hereafter invented, including photocopying and recording, or in any information storage or retrieval system, without permission in writing from the publishers.

Trademark notice: Product or corporate names may be trademarks or registered trademarks, and are used only for identification and explanation without intent to infringe.

British Library Cataloguing-in-Publication Data

A catalogue record for this book is available from the British Library

Library of Congress Cataloging-in-Publication Data

A catalog record for this book has been requested

ISBN: 978-1-4094-2248-8 (hbk)

ISBN: 978-1-315-56895-9 (ebk)

Typeset in Sabon

by Apex CoVantage, LLC 
For Adrian 

Taylor \& Francis http://taylorandfrancis.com 


\section{Contents}

Preface and acknowledgements viii

1 Being and dwelling 1

2 Sensuous dwelling 27

3 Material dwelling $\quad 54$

4 Architectural dwelling $\quad 82$

5 Earthly dwelling 106

6 Being, dwelling and thinking 129

Bibliography 143

$\begin{array}{ll}\text { Index } & 167\end{array}$ 


\section{Preface and acknowledgements}

This book is a conversation about the relationship between anthropology and tourism and like the best conversations it hopes to draw people in by exciting their curiosity and by offering an interesting point of view. I do not assume those of you who read this book think in the same way as me or that you will be convinced by my argument. What I do hope is that by the end of the book most readers will have been able to find something of interest because ultimately I hope to stimulate further conversations about the ideas presented here.

I was inspired to write the book after reading The Perception of the Environment by Tim Ingold. In this book Ingold sets out what he refers to as a dwelling perspective. This perspective was and still is particularly inspiring because at the time of reading the book I was seeking a wider, more holistic understanding of how the activity of tourism can shed light on the experience of being human. Ingold's focus on dwelling as a way of being-in-theworld is a particularly useful way of thinking through tourism because it enables tourism to be located within the totality of life and of living. Within this totality, gazing, mobility, worldmaking, identity, performance and so on, are all aspects of being and dwelling through tourism because they are part of the experience of life.

Given that a basic concern of anthropology is to understand how people who occupy the same space and time in terms of the history and geology of the earth can make very different lives, then it is surprising that anthropologists have yet to fully explore what dwelling through tourism might reveal about the experience of being human. This is what I hope to address with this book.

Although the book's heartbeat is anthropological, there is a slightly undisciplined air about my approach in that it draws from a variety of other disciplines and subject areas when doing so serves to influence my anthropological theorising of tourism. As such, my conversation includes philosophy, sociology, material cultural studies and cultural geography. This reflects the fact that a focus on being human generally and in relation to the meaning-making potential of tourism is not solely the preserve of anthropologists. Contributions from beyond the discipline are included because 
they contribute to anthropology's overarching mission to offer a holistic understanding of human experience.

The thinking that underpins this book draws inspiration from the work of many tourism scholars not all of whom are anthropologists, but all have in numerous ways challenged me to see and think differently. In relation to anthropology I do need to highlight the work of Tim Ingold and Michael Jackson. I am indebted to both of them for two main reasons. Firstly, because how and what they think has produced some of the most stimulating contributions to my conversation, and secondly, because their engaging and eloquent style of writing demonstrates that insight does not have to be complex. Then there is Heidegger.

Heidegger is a major part of this book because it was the discovery of Building Dwelling Thinking, his philosophical essay from the 1950s that inspired me to invite philosophy into my conversation. Whilst some of Heidegger's concepts have had a significant influence on my thinking the dense impenetrability of much of his writing leaves me rather cold. So, I cannot warm to him completely. In addition, my understanding of anthropology differs from that of Heidegger's (1962) who criticised anthropology (together with psychology and biology) for failing to focus on the ontological essence of being human. To my mind there is no such essence to be found through anthropology because anthropology is interested in the similarities and differences among human societies rather than in finding 'an unequivocal and ontologically adequate answer to the question about the kind of Being which belongs to those entities which we ourselves are' (Heidegger 1962: 75 original italic).

My use of Heidegger is, therefore, selective and contextualised within my anthropological approach to understanding human experience in all its fascinating diversity. In using Heidegger I am fully aware of the fact that he is a controversial figure because of his engagement with Nazi Germany, an engagement that has turned him into a sort of philosopher non grata for many academics (see Wolin 2016 for a detailed discussion of politics, philosophy and Heidegger). As a result, using Heidegger can be fraught with difficulties and Thomas (1999) provides a good discussion of the challenges and contradictions of doing so in relation to archaeology. Nonetheless, my conversation will not debate the philosophical technicalities of what Heidegger 'means' or make judgements as to the merits or otherwise of his philosophy; others are far more qualified than I to do so (see Bourdieu 1991; Dreyfus 1991; Philipse 1998; Malpas 2008). Nor will I use tourism to produce a 'reading' of Heidegger. Instead I use Heidegger as the starting point from which to fashion an anthropological interrogation of tourism in order to think through what dwelling through tourism might reveal about the experience of being human.

As indicated above, being for me is about being human in the sense of being alive, as Ingold (2011a) argues in the essays included in his book of that name. Being, for me, is not about an existential search for some form 
of authentic self, which in any case does not exist. What I am interested in is the experience of being human - in-the-world and the hyphenation here is deliberate because it highlights that human and world are as inseparable as mind and body. What humans are, what they think and what they do influences and is influenced by their engagement in (what Heidegger referred to as being absorbed in) the everyday components that make up the world. As, Heidegger argued ' $[t]$ he compound expression 'Being-in-the-world' indicates in the very way we have coined it, that it stands for a unitary phenomenon' (1962: 78, original emphasis).

My philosophical approach to being human-in-the-world aims to think more deeply about the components and activities that people engage with as they construct a meaningful life, activities such as tourism. In this sense, looking beneath the surface of our individual and collective engagement in the world through tourism is no different to the thinking that has opened up other aspects of life such as shopping (Miller 1998a), watching television (Scannell 2014) or hunting for food Willerslev 2007).

There is a caveat to my looking beneath the surface because the tourism that features in my conversation is necessarily one that reflects my AngloWestern outlook. No matter how hard I try to see things through the eyes and experience of someone else I can never truly experience their past or inhabit their present. Likewise, tourism is not an activity open to everyone, and not all those who work in or are affected by tourism are able to exercise agency over their working lives. When I talk about tourism, these realities are always in my mind but they are not the primary focus of this particular conversation.

In addition, my conversation will not be unpicking the influence of politics, economics, technology, the environment and so on, or be exposing issues of power, authority and inequality in each chapter. Of course all such aspects speak of and through culture and the areas I discuss are inherently political and politicised since everything to do with tourism operates in and is conditioned by the global forces of capitalism. It is just to say that the role and implications of what Headrick (1981) refers to as The Tools of Empire are not what drive my thinking at this moment in time. Readers are instead pointed to the rich and extensive literature that already exists related to tourism, a few examples of which are Palmer (1994), Church and Coles (2007), Macleod and Carrier (2010), Huberman (2012) and Bianchi (2014).

I could not have started or finished this conversation without the support of my friends and colleagues at the University of Brighton, Jo-Anne Lester, Helen Atkinson and Tom Carter and of course my family, Adrian, Charlotte and Harry - all of whom have contributed ideas, challenged my thinking, given hugs and produced chocolate at appropriate times. I also need to give a huge thank you to Routledge for their patience in waiting for me to submit the manuscript. I'm afraid my thinking has more in common with the tortoise than the hare. It remains to be said that all the omissions, contradictions, mumbled speech and muddled thinking are my own. 


\section{Being and dwelling}

\section{Introduction}

Much of the literature about tourism seeks to explore and make sense of tourism by adopting approaches that focus on particularities such as visuality, identity, mobility, myth making, tourism as a type of performance, as a networked ordering of modernity, or as a form of globalised consumption or worldmaking. Although such approaches are extremely insightful and important in relation to how we think about, create and experience the world through the activity of tourism, what is missing is a unifying framing within which they can be located. My purpose here is to set out one such framing, a framing woven out of the theoretical threads of anthropology. Threads that above all else seek a wider, more holistic understanding of how the activity of tourism enables us individually and collectively to recognise, to know and to feel that we are human, even though this may well be an unconscious recognition; in effect to shed light on the experience of being human.

In saying this I am not advocating a Grand Theory of everything, as this is neither desirable nor achievable; tourism, as a human experience, is far too complex and multi-faceted to be tied down in such a way. It is too nuanced and intricately woven in with the doing and being of life with thinking and feeling. Furthermore, there are different perspectives on how to approach and how to frame tourism depending upon the questions to be asked and the disciplinary and or ideological allegiance of the individual asking the questions; as Lowenthal once remarked 'every generation finds new facts and invents new concepts to deal with them' (1961: 245). A good example of Lowenthal's point here is the use of performance as a paradigm and a metaphor for exploring and analysing human culture, relationships and behaviour (see Goffman 1969; Turner 1974, 1982). The word and the concept of performance have been adopted by many academics (myself included) as a useful approach for exploring aspects of social life and behaviour. Indeed, the concept of performance has almost become something of a foundation metaphor for describing what tourists do and how tourism works (Edensor 1998; Haldrup and Larsen 2010; Rickley-Boyd et al. 2014). This is despite 


\section{Being and dwelling}

Saldaña's (2006: 1092) poetic denunciation of the way in which performance has been 'overused and abused' by many academic communities. However, my view is that uncovering the complex nuances of everyday life requires a wide angled lens in order to frame the questions to be asked and performance as both paradigm and metaphor is one such lens.

I am continually fascinated by the many and varied philosophical and theoretical positions seeking to explore and to understand the contexts and the consequences of tourism on people, place and nature and the role of tourism in terms of being human (see Selwyn 1996; Franklin 2004; Sheller and Urry 2004; Hollinshead 2007; Ren 2011). The framework I am proposing is contextualised from within an anthropological perspective that views tourism as a significant human activity capable of providing insights into the experience of being human. Or more precisely, experience in the plural, as there is no singular experience but a myriad of experiences from the individual to the collective. Whilst I am not claiming that anthropology is the only discipline interested in meaning making through tourism, I am arguing that anthropology has a unique contribution to make to the study of tourism. This is because anthropologists are interested in people first and foremost, an interest encapsulated in the overarching aim to uncover what being human means and how we make ourselves human (Csordas 1994). Key to understanding the diversity of human experience is to focus on how people live their lives and on the differences and similarities between people, including differing notions of what a 'good life' might mean (Eriksen 2004). Tourism is for many - although by no means all people - a taken-forgranted activity capable of fleshing out what a 'good life' might look and feel like. As the writer Alain de Botton rather succinctly puts it:

If our lives are dominated by a search for happiness, then perhaps few activities reveal as much about the dynamics of this quest - in all its ardour and paradoxes - than our travels. They express, however inarticulately, an understanding of what life might be about, outside the constraints of work and the struggle for survival.

(2002: 9)

Anthropology is particularly appropriate because of the discipline's overarching aim to explore and better understanding the experience of being human in all its fascinating diversity. Within this broad aim social anthropology concerns itself with the social and cultural world of the individual, of societies, groups and communities. This concern manifests itself in the study of culture in its broadest unbounded sense, taking in what is general and specific, tangible and intangible about the lifeworld of others. The concept of lifeworld (lebenswelt) originates with the German philosopher Husserl (1970[1936]) and refers to a world that is familiar, a world that is lived-in and experienced by the individual on a daily basis and from which knowledge, meaning and understanding emerge through involvement with 
both human and nonhuman others. In effect it is the experience of Being Alive (Ingold 2011a) in relation to such as objects, technological systems, animals, nature, the weather and so forth (Buttimer 1976; Seamon 1979; 2000). Nature is significant here as it provides the enveloping context within which life is lived through experience, as Dewey argues:

experience is of as well as in nature. It is not experience which is experienced, but nature - stones, plants, animals, diseases, health, temperature, electricity and so on. Things interacting in certain ways are experience; they are what is experienced. Linked in certain other ways with another natural object - the human organism - they are how things are experienced as well. Experience thus reaches down into nature; it has depth.

(1958: 4a, original emphasis)

Involvement with others thus encompasses all that humans do across the broad spectrum of the lifeworld from hunting for food, weaving cloth and growing crops to driving a car, building a house and going on holiday. As the anthropologist Michael Jackson states 'meaning emerges not from isolated contemplation of the world but from active engagement in it' (2007: xi). Through active engagement the Cartesian-inspired dualism that separates subject and object, mind and body is dissolved in the coming together of doing and thinking, feeling and sensing as expressions of human existence. In effect to be embedded in the world, what Heidegger described as being-in-the-world. In highlighting the significance of experience I am aligning myself with an approach closely associated with Jackson, that of phenomenological anthropology. Here everyday life provides the key to thinking about and understanding the human condition, 'thought is always tied to mundane interests, material matters, cultural preoccupations and everyday situations' as such anthropology should focus on 'how thought may be anchored in rather than abstracted from human lifeworlds' (Jackson 2009: 236).

I am interested in what might emerge as a result of thinking in relation to tourism since tourism is for many people part of everyday life whether this is in terms of working in tourism or dreaming about tourism. It is worth noting at this point that references to everyday life or for that matter to the lifeworld should not ignore the fact that there are a myriad of different everyday lives and lifeworlds, many of which are experienced as a cold, hungry fight for survival. The everyday life of a miner for example is very different to that of the mine owner; the farm worker to that of the farm owner and so on, such that like culture everyday life 'must be situated, placed in a context historically, economically, politically’ (Keesing 1987: 162).

Among the most significant aspects of the lifeworld of interest to anthropologists are those relating to the where, how and under what conditions people live out their lives. For example the spaces and places in which people live, the social relationships and beliefs by which they live and the political, 


\section{Being and dwelling}

economic and environmental conditions within and against which they live, including the systems adopted for maintaining order and social cohesion. These conditioning constituents inform, transform, maintain or disrupt human social activity and thereby frame the ways in which individuals engage with and in the world around them. This engagement in the world has been studied from a variety of different yet frequently interweaving perspectives. Perspectives that have become established themes within the pantheon of anthropological theory such as work, play, faith, customs, kinship and cosmology. However, these themes are not exhaustive as the scope of anthropological enquiry necessarily reaches far and wide in its uncovering of what it means to be human. So, alongside the established themes the richness and depth of the human experience is also revealed in theorising linked to aspects such as 'Power, Change ... Oppression ... Passion, Authority, Beauty, Violence, Love, Prestige' (Geertz 1973: 21); through aesthetics, the senses, language and technology, and as a consequence of acknowledging contested experiences of the world (Asad 1973; Herzfeld 2001).

The effect of tourism on culture is what first brought tourism to the attention of anthropologists (Nunez 1963; Boissevain 1977; Crick 1994). An early focus on tourism as an agent of cultural change predominantly in relation to the effect of Western cultures on the lives of non-Western peoples has evolved into what is now a substantial body of knowledge about tourism from a variety of perspectives (see, Graburn 1976; Selwyn 1996; NadelKlein 2003; Tucker 2003; Nyíri 2006; Kolas 2008; Andrews 2011; Picard 2011; Huberman 2012). Anthropologically, tourism is one of the ways in which people access physically and through imaginative reverie the social and cultural particularities of other people, places and times. It is also a means by which the tourist can access and experience identity as demonstrated by some fascinating studies of what being a tourist means (Harrison 2003; Andrews 2009; 2011).

It is no surprise, therefore, that anthropologists are interested in tourism and tourists, in destinations and resident communities. However, the 'other' in tourism is not necessarily far away since diversity and difference, the exotic and the extraordinary can be found next door to where people live, in the next street or the next town, such that anthropologists are as fascinated by the near as they are by the elsewhere (Augé 2008). Or as Clifford maintains " "[c]ultural" difference is no longer a stable, exotic otherness'; the exotic, the different and the unexpected are nearby; they can be encountered in the adjoining neighbourhood (1988: 14). Notions of the exotic are of course relational as Dennis O'Rourke's 1987 film Cannibal Tours clearly demonstrates the Western tourists appear exotic, strange and at times incomprehensible to the people of Papua New Guinea.

Difference that is near is characterised by the same sort of signifying practices associated with the elsewhere; it is reflected in where and how people choose to live, in the food they buy and how they choose to eat it, in the clothes they wear and the ways in which they use and adorn their bodies. 
It is reflected in the choices people make about whether and how to engage in tourism about what travel and travelling mean within the totality of the lives people lead. In Western culture if we take aside travel associated with daily need such as shopping for food and clothes, going to work, collecting children from school, then non obligatory travel has long been associated with personal growth, relaxation and an expansion of self-awareness whether this is in terms of spiritual development, or for reasons of intellectual, political or aesthetic advancement as with the eighteenth-century Grand Tour of an educated, wealthy European elite.

Of course non-Western cultures also travel for pleasure and it is important to remember that tourism is not a modern invention as people travelled in ancient and medieval times, and from within the Near and the Far East (Casson 1994; Guichard-Anguis and Moon 2008), but there are differences in the philosophical understanding of the role and purpose of travel between Western and non-Western peoples. Such differences reflect alternative approaches to the nature of existence and to the relationship between the self, the state, the ancestors and the natural world (Nyíri 2006; Morphy 1995). Tourism and travelling not only mean different things to different people, they are also understood differently depending upon the context and the perspective within which they take place. Early motivations for travel rooted in trade, migration and religious pilgrimage have evolved in different ways such that today a Christian worldview has for the most part interpreted tourism and travelling in relation to the playful pursuit of pleasure. Whereas an Islamic worldview interprets travel as a search for spiritual knowledge through pilgrimage and therefore distances itself from the type of behaviour associated with the indulgence and hedonism of international mass tourism (Aziz 2001; Din 1989) Although these generalisations belie the fact that international tourism does not have to be incompatible with Islam (Okhovat 2010; Sanad et al. 2010; Henderson 2010), both are illustrative of different understandings about how the world is constructed and how individuals should behave, what anthropologists refer to as cosmology.

\section{Cosmology and tourism}

Cosmology is a significant concept in anthropology because as Mary Douglas (1996) points out, it serves to justify and explain behaviour, which in turn reveals something about the basis upon which a society operates. As Wagner states:

In every "culture", every community or communicating human enterprise, the range of conventional contexts is centered around a generalized image of man and human relationships, and it articulates that image. These contexts define and create meaning for human existence and human sociality by providing a collective relational base, one that can be actualized explicitly or implicitly through an infinite variety of 
possible expressions. They include such things as language, social "ideology", what is called cosmology.

(1981: 40, original emphasis)

To talk about a cosmology is then to talk about the basic belief system or worldview of a particular group or society, how people live, how they think about, imagine and understand their place in the world, how power is exercised, the relationship between the social order, between production and consumption and so forth. Cosmology is not only a scientific term for the universe or cosmos beyond the boundary of the earth's dominion, it is also a religious and hence cultural term that speaks of the knowledge, ideas and beliefs a people have about how they came to be in the world, how the world is and should be organised and about the existence or otherwise of 'life' beyond the veil of death. Despite the clear synergies with religion and stories of creation that seek to explain human existence, I prefer to think in terms of faith as the means by which ideas about the sacred, spirituality and the supernatural are located within culture. Faith is less culturally specific than religion, although both are inherently cosmological.

A cosmological system is, therefore, concerned with the maintenance of order through the setting of boundaries as to what is acceptable and what is unacceptable in any given situation. The basic principles and values of a particular worldview define the rules that govern behaviour in terms of social relationships, gender divisions, economics and so forth. In addition, a society's understanding of and relationship with nature, animals, the physical and material environment as well as attitudes towards death and the notion of time all coalesce to form an overall cosmological system. Cosmology is then a way of situating the self in the whole; a way of being, thinking and doing that makes life meaningful for individuals on their journey between birth and death, including how the time before birth may be understood (Lytton 1989; Weiner 2001; Hornborg 2006).

A cosmology is made manifest in the practices and social arrangements enacted by a society as Comaroff and Comaroff (1992: 6) argue in relation to Western ways of being 'many of the concepts on which we rely to describe modern life - statistical models, rational choice and game theory . . . case studies and biographical narratives ... are our own rationalizing cosmology posing as science, our culture posing as historical causality'. It is clear from this that questions about cosmology cannot be confined to indigenous tribal societies; they are just as pertinent for the contemporary world and for societies driven by technological innovation (Abramson and Holbraad 2014). The continuing relevance of cosmology should not be taken to imply that cosmologies are inherently stable. As Douglas reminds us, a cosmology is not fixed in stone; it is more a set of categories that are as it were 'in use':

It is not a hard carapace which the tortoise has to carry for ever, but something very flexible and easily disjointed. Spare parts can be fitted 
and adjustments made without much trouble. Occasionally a major overhaul is necessary to bring obsolete sets of views into focus with new times and new company ... most of the time adjustments are made so smoothly that one is hardly aware of the shifts of angle until they have developed an obvious disharmony between past and present.

(1996: 158)

Although cosmologies can and do change, the means by which they change may not always be as straightforward or as smooth as Douglas suggests. For example Malkki (1995) provides an unsettling ethnography of the opposing narratives laying claim to the historical background that led to the 1972 massacre of Hutus by the Tutsi in Burundi. Arguing that the differing versions of history are not just a struggle over what happened but also a struggle over opposing cosmologies.

Despite this example, the concept of cosmology is useful for exploring the meaning-making potential of tourism because tourism provides the meeting grounds for particular worldviews. Through tourism different beliefs and values come into contact with each other within the context of what I have referred to elsewhere as 'tourist society' (Palmer 2009). In this society social relationships are made, remade, celebrated, tested and broken in relation to the values influencing what is considered to be acceptable ways of behaving. So is it possible, therefore, to talk of there being a cosmology of tourism? I think it is and my view here is inspired by Miller's (1998a) anthropological essay on the significance of shopping for understanding the values that influence and sustain social relationships. Miller's specific intention is to establish the cosmological foundations of routine shopping through an analysis of shopping practices on one street in North London. By drawing upon the analogy between shopping and the rituals associated with ancient sacrifice, Miller reveals the fundamental values inherent in a cosmology of shopping, values such as devotional love, the aesthetics of thrift and selfsacrifice. Although Miller's ethnography is highly circumscribed in relation to the confines of his study, it does illustrate how social order and social relationships can be maintained, reinforced and/or subtly transformed by a particular cosmology.

Transformation through travel whether in terms of the self or in relation to others is well documented in the literature (Cone 1995; Noy 2004; Devereux and Carnegie 2006; Smith and Kelly 2006; Østergaard and Christensen 2010; Picard and Robinson 2012), and the link between cosmology and the transformative potential of tourism is certainly worth investigating. As is the wider cosmological framework within which tourists interact with each other, with resident communities, with the destination and with the organisational components of travelling. However, cosmology as a concept has yet to be fully explored within tourism, although its applicability for understanding tourism, tourists and local people is to my mind obvious. For example, the denigration of tourists as reflective of a cosmology 


\section{Being and dwelling}

that associates the West and outsiders generally with corruption, depravity, hedonism and decay has been noted by Crick in relation to Sri Lanka such that '[i]nternational tourists, in this cosmology, are sometimes clearly seen as just another source of social ill, as are Tamils and anything else alien' (1994: 58). Likewise, in their introduction to the journal Tourism and Cultural Change Robinson and Phipps (2003) tantalisingly refer to tourism as the cosmological pursuit of pleasure, stimulation, relaxation and stories.

Cosmology is referred to but not explored at length in relation to tourists' exposure to and experience of indigenous cosmologies for example Medina (2003), Ryan and Crotts (1997), Wright et al. (2009). There is, however a desire to engage more specifically with the cosmological significance of tourism. Picard and Di Giovine (2014) argue that contemporary tourism is shaped by a modernist cosmology that shapes understandings of the Other and Otherness. Campo and Turbay (2015) offer a fascinating account of how the cosmology of the Kogi people of Colombia provides them with a rhetorical strategy of resistance, a strategy of silence when confronted by outsiders, which in this instance are the tourists.

A cosmological theme underpins Bird's (2011) research into tourism and remembrance within the context of the D-Day landing of Allied forces onto the beaches of Normandy in World War II. According to Bird the D-Day experience, the beaches, the guided tours, the cemeteries, museums, reenactments, significant locations, landmarks and memorial events can be conceptualised as a cosmology of remembrance. Such a cosmology not only positions the beaches and associated landmarks as being worthy of remembrance, it also sets the framework for why the D-Day landings should be remembered at all. In this cosmology place, time and the senses are significant actors in the tourism industry's interpretation of what constitutes a meaningful experience for tourists (Bird 2011). Meaning in this context relates to an affirmation of the values and beliefs worth dying for and of the ultimate triumph of good over evil.

Cosmology as a system of values and beliefs is just as meaningful in relation to mundane taken-for-granted practices such as shopping and tourism as it is in relation to the divine. In highlighting the cosmological significance of shopping Miller presents a forceful counterpoint to the prevailing tendency to 'glibly' dismiss 'the world's favourite object of scorn' (1998a: 155). Tourism like shopping is frequently viewed as frivolous both as an activity and as a focus of academic study. But to say that tourism is mundane is not the same as saying it does not matter; it is rather an acknowledgement of the embeddedness of tourism in terms of what people do. As Scannell (2014: 208) illustrates in relation to watching TV ' $[t]$ elevision today is routinely experienced everywhere as part of the ordinary life-world of members of modern societies, and watching it is just one of those things that most of us do in the course of an ordinary day'.

Although, a debate can be had over the extent to which tourism (or watching television) is an activity open to all people, or one that is a recognisable feature in all cultures, as clearly it is not. However, despite the existence of 
inequalities across and within societies, to travel, to go on holiday, to visit places of interest is endemic. This is so beyond the usual borders of Western practice and thinking as illustrated by the body of research on the meaning and significance of tourism in Asia, Latin America, China, Africa and the Middle East (Tan et al. 2001; Nyíri 2006; Notar 2007; Winter et al. 2008; Guichard-Anguis and Moon 2009; Ryan and Huimin 2009).

\section{Thinking as philosophy}

In accepting that tourism does matter, my purpose here is to explore what thinking through tourism might contribute to an understanding of the cosmological significance of tourism. In so doing I am responding to the aim of Scott and Selwyn's (2010: 1) edited collection Thinking Through Tourism seeking 'to reflect on the contributions anthropology, tourism and tourism studies make to each other'. My approach to thinking is philosophical in that I intend to look beneath the surface of our individual and collective engagement with tourism to better understand why it matters beyond references to escapism, relaxation and so on. Henare et al. (2007) provide a useful illustration of what thinking anthropologically means in the introduction to their book Thinking Through Things. Here they argue that thinking is about method rather than theory, it is about bringing something to the surface as opposed to an analysis of things or objects per se. Miller's analysis of shopping as sacrifice rather than as an economic activity is a case in point, 'an analogy with sacrifice should open up the possibility that shopping is a practice that might have ritual structure, that might be involved in the creation of value and relationships and that might manifest elements of cosmology' (1998a: 113). Miller's approach resonates with the social scientific study of tourism, particularly in relation to concepts such as magic, pilgrimage, ritual and myth (Graburn 1983; Selwyn 1996; Picard 2011).

Although conceptual analogies are certainly useful, they need to be situated within a wider framework capable of elucidating what engaging in tourism might reveal about the human experience, a framework that draws inspiration from the theoretical intertwining of anthropology, philosophy and tourism studies. In this respect I wish to acknowledge the influence of the anthropologists Tim Ingold and Michael Jackson, both of whom have inspired me to explore what being human might look and feel like by subjecting the practical experiences of human existence to philosophical scrutiny. In this instance practical experience that comes through engagement with the activity of tourism. Their philosophical endeavours are firmly rooted in the familiar everyday lives of people, what Jackson refers to as 'practical skills and know-how' (2009: 244) rather than in the rarified world of conceptual distance. As Ingold argues philosophers rarely:

enlist the help of ordinary people in their enterprise, or test their insights against the wisdom of common sense. Anthropology is a kind of philosophy too, but it is not so exclusive. There are, of course, as many 
definitions of anthropology as there are anthropologists but my own is as follows: Anthropology is philosophy with the people in.

(1992: 696, original emphasis)

Whilst Ingold's critique of philosophers can be challenged by, for example the work of the political philosopher Michael Sandel, including his radio series for the BBC entitled The Public Philosopher, such a definition puts people, the everyday, the mundane and ordinary experiences of life firmly at the forefront of any attempt to understand the dynamics of the human condition. What Lakoff and Johnson (1999) refer to as 'philosophy in the flesh'. Philosophy is valued and is valuable for my purposes in so far as it helps to illuminate, rather than obscure, what it means to live as a human being. Or more precisely some of the ways in which being human is experienced because, as noted earlier there is not one universal human experience but rather a multitude of experiences, many of which are neither comfortable nor safe nor come anywhere near to an experience of what a 'good life' might mean.

This is an important point because I am not concerned with or even interested in subjecting philosophy and philosophical arguments to critical enquiry. I do not intend to engage with and in debates about the metaphysics of reality or truth; which is not to say that such things cannot or should not be undertaken but rather to state that this is not the type of philosophising in which I wish to engage. To do so would be to separate tourism from its moorings and set it adrift in a sea of mystery divorced from the very thing that gives it meaning and purpose, life as it is lived as it is experienced by human beings.

Concepts and complexity should not as Jackson argues (1995: 5) 'cut up experience' because this condenses the fullness of the lifeworld into just those aspects that can be named. And as numerous ethnographies have shown, words alone cannot describe or ever fully explain the lived experience of other people. This is because knowledge is not communicated solely through linguistics but also through showing, doing and imagining, through myths, symbols and images, through art, nature and the senses (see Wierzbicka 2008; Boivin et al 2007; Geurts 2002; Bloch 1991; Levi-Strauss 1986). Concepts and the search for wisdom should illuminate a path through a forest rather than push us further on into the forest. According to Dewey, an assessment of the value of narrative abstraction in philosophy should be based upon the following test:

Does it end in conclusions which, when they are referred back to ordinary life-experiences and their predicaments, render them more significant, more luminous to us, and make our dealings with them more fruitful? Or does it terminate in rendering the things of ordinary experience more opaque than they were before, and in depriving them of having in "reality" even the significance they had previously seemed to 
have? Does it yield the enrichment and increase of power of ordinary things ... Or does it become a mystery that these ordinary things should be what they are; and are philosophic concepts left to dwell in separation in some technical realm of their own?

Any search for meaning through tourism cannot be divorced from the activity and pursuit of tourism from the moving and the standing still, from the doing, thinking, reflecting, feeling and sensing that permeate engagement with tourism. My anthropological unravelling of the cosmological significance of tourism thus takes shape from within what Ingold (1993, 1995, 2011b) has referred to as a dwelling perspective, a perspective that owes its inception to the German philosopher Martin Heidegger's (2001) concept of dwelling-in-the-world. Heidegger's philosophy has proved fruitful for social scientists from a wide range of subject areas and disciplines such as geography, anthropology, archaeology, architecture, sociology, environmental sciences, media and communication, business and management, nursing and health. Despite the fact that many of Heidegger's ideas 'have filtered down into the culture at large' (White 2005), the significance of a dwelling perspective for tourism studies has yet to be fully explored or developed.

In saying this I do not mean that Heidegger's work has not been influential, as clearly it has. One of the reasons why his ideas continue to resonate is because he puts the practical everydayness of life centre stage, as part and parcel of what being-in the world means. Our mode of existence, our being-in or being-there in the world is referred to by Heidegger (1962) as Dasein, a derivative of the German words $d a$ meaning here and sein meaning to be. According to Heidegger we are not alone in the world; we are engaged in and with the world around us as part of a wider community. In this sense he is arguing that people are not bystanders or spectators in life but engaged actors whose very existence is understood through encounters with things and with others (Steiner 1989; Polt 1999). Given that tourism is a well-established human activity as opposed to something that is separate to or outside of the everyday, then it is understandable that Heidegger has influenced scholars of tourism. My point is rather that this influence is confined and concentrated, albeit in the form of some thoughtful and intelligent explorations of Heidegger's relevance for tourism.

In this respect I would highlight the work of Steiner and Reisinger, who have published several stimulating analyses of the significance of Heidegger in relation to existential authenticity, the search for an 'authentic' self (Reisinger and Steiner 2006; Steiner and Reisinger 2006a, 2006b). However, Cohen (2012) has criticised their use of obscure and highly abstract Heideggerian terms whose relevance for the theoretical and empirical study of tourism is unclear. Shepherd makes a more specific critique of discussions linking existential authenticity in tourism with Heidegger, arguing that these are based on a misreading of Heidegger. However, he goes on to state that 


\section{Being and dwelling}

his concerns are not about the relevancy of existential authenticity, but with the relevancy of Heidegger to the field of tourism studies.

These critiques notwithstanding, Heidegger's philosophy has provided a conceptual framework based around existential authenticity and the concept of Dasein, most notably in relation to the metaphorical essence of Being in tourism, or in terms of objects or wellness (Lau 2010; Larsen 2008; Kim and Jamal 2007; Wang 1999; Harkin 1995). Likewise, Pernecky (2010) opens up an interesting avenue in his exploration of the relationship between the being of tourism and peace, and there has been a call to recognise the significance of Heidegger for phenomenological research with a particular focus on hermeneutics (Pernecky and Jamal 2010; Ablett and Dyer 2009). Indeed, Pernecky and Jamal provide an astute analysis of the value of hermeneutic phenomenology for tourism by drawing upon the differing phenomenological positions of Heidegger and his mentor Husserl.

A concept of dwelling and travelling derived from Clifford (1997) as opposed to Heidegger is discussed by Ingold, whose own influence within tourism studies is emerging, most notably in the work of Vannini (2012). Lury (1997) employs 'dwelling-in-travelling and travelling-in-dwelling' to illustrate the implications for tourism of the capacity of objects such as souvenirs, T-shirts, postcards and photographs to both travel and to stay still. In terms of Heidegger's concept of dwelling, Urry (2000, 2007), ObradorPons (2003) and Jamal and Stronza (2009) are notable in exploring the dwelling concept beyond the level of brief references to it, as is the case with some of the studies mentioned above. However, Urry's focus on dwelling is part of his wider sociological analysis of mobility and Obrador-Pons has so far confined his use of dwelling to a discussion of embodiment and tourist agency. Finally, Edensor's (2002) dwellingscapes draws from Ingold to illustrate how understandings of identity are constructed in and through engagement with the spaces and places that are part of daily life.

Interestingly, Steiner and Reisinger (2006a) criticise Obrador-Pons for what they see as his inadequate engagement with philosophical concepts because he changes Heidegger's concept of existential dwelling to dwelling as metaphor. Such a view highlights the minefield that awaits anyone attempting to bring philosophical abstractions into lived experience. There will always be questions asked as to whether this should or even can be done and how effective or otherwise is the end result. As Al-Mohammad rather pointedly puts it, the metaphysical is not an ontic category, it is not a body or a thing to be investigated, it is ontological:

We cannot use our experiences, nor the experiences of others, to support or negate Heidegger's (or any metaphysician's) claim as there can be no phenomenal basis for critiquing claims about the nature of reality, the nature of human beings and the nature of their constitution.

(2011: 126) 
The difficulty I have with such a view, however obvious it might seem on the surface, is that the value and usefulness of philosophy lies in its ability to open up a dialogue around fundamental questions of human existence, ' $[\mathrm{a}] \mathrm{s}$ Heidegger likes to put it, the task of a philosopher is to alert us to what is worthy of questioning' (Polt 1999: 7) and in so doing enrich understanding of what being human means in relation to life as it is lived, experienced and imagined. Metaphor can be very useful here, as Jackson argues metaphors make people whole by revealing the unities that bring self and world, mind and body together, 'metaphors coalesce social, personal, and natural aspects of Being, as well as unifying ideas and practices' (1989: 149).

I would have thought that the experiences of self and other are crucial here and indeed have been shown to be so through several significant ethnographies inspired by and interpreted within a philosophical framework. For example, Jackson's (1995) ethnographic exploration of the meaning of home both existentially and metaphorically, Ingold's (1995) Building, Dwelling, Living: How Animals and People Make Themselves at Home in the World and Weiner's (2001) Heideggerian anthropology of the Foi language of Papua New Guinea. In addition, Willerslev's (2007: 22) interpretation of the Yukaghirs of northeastern Siberia, employs Heidegger's theory of being-in-the-world to re-evaluate what he refers to as 'the animism problem' in anthropology. Basso (1996) draws on Husserl and Heidegger as inspiration for his goal of creating an 'ethnography of lived topographies' in relation to the ways in which Apache peoples use names and stories to create places in the landscape. Gray's (1999) ethnography of sheep farm practices employs Heidegger's dwelling concept and his use of Umwelt. So, if using a concept like dwelling as a metaphor helps to further the philosophical imperative then so be it, as Lakoff and Johnson argue in their book Metaphors We live By:

The concepts that govern our thought are not just matters of the intellect. They also govern our everyday functioning, down to the most mundane details ... how we get around in the world, and how we relate to other people ... the way we think, what we experience, and what we do every day is very much a matter of metaphor.

(1980: 103)

Furthermore taking concepts derived from one field and applying them to another is not necessarily a problem as long as their origins and their reuse is explained and justified. Turner (1978) used selected concepts from Freud's The Interpretation of Dreams to help him in his analysis of Ndembu ritual symbols such as the Blood Tree and the Milk Tree. Freudian concepts such as sublimation and projection were used analogously and metaphorically by Turner as a way of gaining some initial purchase on his data. However, Turner makes it clear that he was inspired by Freud's way of thinking rather 


\section{Being and dwelling}

than by his hypotheses, arguing that although psychology cannot be used to explain social facts:

one can learn a great deal from the way a master thinker and craftsman works with data ... It was his style of thinking and working which gave me encouragement rather than his actual inventory of concepts and hypotheses. None of these could be applied mechanically or literally to the data I had collected.

(1978: 582, original emphasis)

\section{Thinking and Heidegger}

In bringing tourism within the realm of anthropology and philosophy I am aligning myself with Jackson's view that philosophy 'is a mode of being-inthe-world, and as such is inextricably a part of what we do, what we feel, and what we reckon with in the course of our everyday lives' (2009: 246). Although Heidegger's philosophy provides the inspiration for my thinking, as much as I like the intellectual challenge of my encounters with his work the at times dense impenetrability of his writing leaves me a little cold. I find that I cannot warm to his soul completely. Supporters of Heidegger such as Dreyfus (1991), White (2005), and Malpas (2008) all acknowledge the difficulties in reading, let alone interpreting, his thinking with White using adjectives such as 'murky', 'cryptic' and 'misleading' to describe Heidegger's style of writing. It is no surprise, therefore, when critics highlight this problem of language, which has variously been described as full of 'baffling complexity' (Philipse 1998: 3), as comprising 'mind-boggling abstractions' (Morris 1997: 323) and as the translation of 'meaningless German into meaningless English' (Edwards 1989: 470).

Within anthropology Miller finds Heidegger's writing 'incomprehensible and obscure, and much of its contemporary use pretentious' (2007: 24). Even Ingold limits his engagement with Heidegger and considers it a waste of time to read all of his work, 'I never read the whole corpus of Heidegger's work. ... People who read too much of it get infected with a kind of virus and can't write coherently any more. So I've kept Heidegger at a distance' (2003: 11). However, White concludes that criticisms of philosophical language are rather boring and beside the point if there is something interesting to be said and 'Heidegger does have something insightful to say, and his dense writing results from the complexity and depth of the issues with which he is dealing' (2005: li).

While this may be so, philosophy about the meaning of life, about what it means to be human, needs to capture and communicate the liveliness and livedness of life, the vitality and warmth as well as the weary coldness that far too many people experience as life. So, although Heidegger's philosophy may be seeking to question the meaning of life in terms of its ontological construction, it is not life as it is lived. In many ways Heidegger's thinking 


\section{References}

Ablett, P. G. and Dyer, P. K. (2009) Heritage and Hermeneutics: Towards a Broader Interpretation of Interpretation. Current Issues in Tourism, 12 (3): 209-233.

Abramson, A. and Holbraad, M. (2014) Introduction: The Cosmological Frame in Anthropology, in Framing Cosmologies: The Anthropology of Worlds, edited by A. Abramson and M. Holbraad . Manchester: Manchester University Press, pp. 1-28.

Adams, K. (1984) Come to Tana Toraja, "Land of the Heavenly Kings": Travel Agents as Brokers of Ethnicity. Annals of Tourism Research, 11 (3): 469-485.

Adey, P. (2008) Architectural Geographies of the Airport Balcony: Mobility, Sensations and the Theatre of Flight. Geografiska Annaler: Series B, Human Geography, 90 (1): 29-47.

Adey, P. (2010a) Aerial Life: Spaces, Mobilities, Affects. Chichester: Wiley-Blackwell. Adey, P. (2010b) Mobility. London: Routledge.

Al-Mohammad, H. (2011) Less Methodology More Epistemology Please: The Body, Metaphysics and 'Certainty'. Critique of Anthropology, 31 (2): 121-138.

Ames, M. (1992) Cannibal Tours and Glass Boxes: The Anthropology of Museum, 2nd ed. Vancouver: University of British Columbia Press.

Amsinck, P. (1810) Tunbridge Wells and Neighbourhood. London: William Miller.

Anderson, B. (1991) Imagined Communities, 2nd ed. London: Verso.

Anderson, T. (2011) Complicating Heidegger and the Truth of Architecture, in The Aesthetics of Architecture: Philosophical Investigations into the Art of Building, edited by D. Goldblatt and R. Paden . Chichester: Wiley-Blackwell, pp. 69-79.

Andreu, P. (1999) Borders and Borderers, trans. G. Walker, in Architecture of the Borderlands, edited by T. Cruz and A. Boddington . Chichester: Academy Editions, Wiley-Blackwell, pp. 56-61.

Andrews, H. (2005) Feeling at Home: Embodying Britishness in a Spanish Charter Tourism Resort. Tourist Studies, 5 (3): 247-266.

Andrews, H. (2009) Tourism as a 'Moment of Being'. Suomen Antropologi: Journal of the Finnish Anthropological Society, 34 (2): 5-21.

Andrews, H. (2011) The British on Holiday: Charter Tourism, Identity and Consumption. Bristol: Channel View publications.

Appadurai, A. (ed) (1986) The Social Life of Things: Commodities in Cultural Perspective. Cambridge: Cambridge University Press.

Arbid, M. (2015) Toward a Neuroscience of the Design Process, in Mind in Architecture:

Neuroscience, Embodiment, and the Future of Design, edited by S. Robinson and J. Pallasmaa . Cambridge, MA: The MIT Press, pp. 75-98.

Arendt, H. (1958) The Human Condition. New York: Doubleday Anchor Books.

Asad, T. (ed) (1973) Anthropology and the Colonial Encounter. London: Ithaca Press.

Aslet, C. (1997) Anyone for England? A Search for British Identity. London: Little \& Brown.

Augé, M. (2008) Non-Places: An Introduction to Supermodernity, 2nd ed. London: Verson.

Aziz, H. (2001) The Journey: An Overview of Tourism and Travel in the Arab/Islamic Context, in Tourism and the Less Developed World: Issues and Case Studies, edited by D. Harrison .

Wallingford: Channel View, pp. 151-159.

Bachelard, G. (1994 [1958]) The Poetics of Space, trans. M. Jolas . Boston, MA: Beacon Press. Bærenholdt, J. , Haldrup, M. , Larsen, J. and Urry, J. (2004) Performing Tourist Places. Farnham: Ashgate.

Bal, M. (2004) Telling Objects: A Narrative Perspective on Collecting, in Grasping the World: The Idea of the Museum, edited by D. Preziosi and C. Farago . Aldershot: Ashgate, pp. 84-102. Barth, F. (1969) Introduction, in Ethnic Groups and Boundaries: The Social Organization of Culture Difference, edited by F. Barth . London: Allen and Unwin, pp. 9-38.

Barthes, R. (1979) The Eiffel Tower and Other Mythologies. New York: Hill and Wang.

Basso, K. (1996) Wisdom Sits in Places: Notes on a Western Apache Landscape, in Senses of Place, edited by S. Feld and K. Basso . Santa Fe: School of American Research Press, pp. 53-90.

Basu, P. (2007) Highland Homecoming: Genealogy and Heritage Tourism in the Scottish Diaspora. Abingdon, Oxon: Routledge.

Bauby, J-D. (1998) The Diving-Bell and the Butterfly, trans. J. Leggatt . London: Fourth Estate. 
Bawaka Country, Wright, S. , Suchet-Pearson, S. , Lloyd, K., Burarrwanga, L. , Ganambarr, R. , Ganambarr-Stubbs, M. , Ganambarr, B. , Maymuru, D. and Sweeney, J. (2016) Co-Becoming Bawaka: Towards a Relational Understanding of Place/Space. Progress in Human Geography, 40 (4): 455-475.

Behr, R. (2010) An Englishman's Home Is His Castle, If He Can Get One. The Guardian [online], 3rd January. Available at: www.theguardian.com/commentisfree/2010/jan/03/propertyprices-house-building [accessed 30th June 2014].

Bell, D. (2003) Mythscapes: Memory, Mythology, and National Identity. British Journal of Sociology, 54 (1): 63-81.

Ben-David, R. (2013) Hunting the Wild 'Other' to Become a Man: Wildlife Tourism and the Modern Identity Crisis in Israel Safaris to East Africa, in Living Beings: Perspectives on Interspecies Engagements, edited by P. Dransart . London: Bloomsbury, pp. 125-144.

Ben-Ze'ev, E. (2004) The Politics of Taste and Smell: Palestinian Rites of Return, in The Politics of Food, edited by M. E. Lien and B. Nerlich . Oxford: Berg, pp. 141-160.

Bender, B. (2002) Time and Landscape. Current Anthropology, 43 (Supplement): S103-S112.

Benjamin, W. (1973) Charles Baudelaire: A Lyric Poet in the Era of High Capitalism, trans. H. Zohn . London: New Left Books.

Benjamin, W. (1999) The Arcades Project, trans. H. Eiland and K. McLaughlin . Cambridge, MA: Belknap/Harvard University Press.

Bennett, J. (2001) The Enchantment of Modern life: Attachments, Crossings, and Ethics.

Princeton: Princeton University Press.

Bianchi, R. (2014) Towards a New Political Economy of Global Tourism Revisited, in Tourism and Development: Concepts and Issues, 2nd ed, edited by R. Sharpley and D. Telfer . Bristol: Channel View Publications, pp. 287-331.

Bird, G. (2011) Tourism, Remembrance and the Landscape of War. Unpublished PhD Thesis, University of Brighton.

Birth, K. (2012) Objects of Time: How Things Shape Temporality. New York: Palgrave MacMillan.

Bishop, P. (2013) Surveying 'The Waiting Room'. Architectural Theory Review, 18 (2): 135-149. Blencowe, R. W. (1858) Cowden and Its Neighbourhood. Archaeologica Cantiana, 1: 111-123. Bloch, M. (1991) Language, Anthropology and Cognitive Science. Man (N.S.), 26 (2): 183-198. Bloch, M. (1995) The Resurrection of the House Amongst the Zafimaniry, in About the House: Levi-Strauss and Beyond, edited by J. Carsten and S. Hugh-Jones . Cambridge: Cambridge University Press, pp. 69-83.

Bloch, M. (2005) Essays on Cultural Transmission. Oxford: Berg.

Bloomer, K. C. and Moore, C. W. (1977) Body, Memory, and Architecture. London: Yale University Press.

Boissevain, J. (1977) Tourism and Development in Malta. Development and Change, 8: 523-538.

Boivin, N. , Brumm, A. , Lewis, H. , Robinson, D. and Korisettar, R. (2007) Sensual, Material, and Technological Understanding: Exploring Prehistoric Soundscapes in South India. Journal of the Royal Anthropological Institute (N.S.), 13 (2): 267-294.

Botton, A. de. (2002) The Art of Travel. London: Hamish Hamilton.

Botton, A. de. (2007) The Architecture of Happiness. London: Penguin.

Botton, A. de. (2009) A Week at the Airport: A Heathrow Diary. London: Profile Books.

Bourdieu, P. (1977) Outline of a Theory of Practice. Cambridge: Cambridge University Press.

Bourdieu, P. (1979) Algeria 1960: The Disenchantment of the World. Cambridge: Cambridge University Press.

Bourdieu, P. (1990) The Logic of Practice. Cambridge: Polity Press.

Bourdieu, P. (1991) The Political Ontology of Martin Heidegger, New ed. Stanford: Stanford University Press.

Brace, C. (2003) Rural Mappings, in Country Visions, edited by P. Cloke. Harlow: Pearson, Prentice Hall, pp. 47-72.

Britton, S. G. (1982) The Political Economy of Tourism in the Third World. Annals of Tourism Research, 9 (3): 331-358.

Bruner, E. (1991) Transformation of Self in Tourism. Annals of Tourism Research, 18 (2): 238-250. 
Buchli, V. (2013) An Anthropology of Architecture. London: Bloomsbury.

Burdea, G. C. and Coiffet, P. (2003) Virtual Reality Technology, 2nd ed. Hoboken, NJ: Wiley.

Buttimer, A. (1976) Grasping the Dynamism of Lifeworld. Annals of the Association of American Geographers, 66 (2): 277-292.

Byng-Hall, J. (1990) The Power of Family Myths, in The Myths We Live By, edited by R. Samuel and P. Thompson . London: Routledge, pp. 216-224.

Caffyn, A. (2012) Advocating and Implementing Slow Tourism. Tourism Recreation Research, 37 (1): 77-80.

Calder, A. (1991) The Myth of the Blitz. London: Pimlico.

Campo, A.R.R. and Turbay, S. (2015) The Silence of the Kogi in Front of Tourists. Annals of Tourism Research, 52: 44-59.

Cannon, W. (1963) The Wisdom of the Body, revised and enlarged ed. New York: Norton.

Carsten, J. and Hugh-Jones, S. (eds) (1995) About the House: Levi-Strauss and Beyond.

Cambridge: Cambridge University Press.

Casey, E. (2009) Getting Back into Place: Toward a Renewed Understanding of the Place-

World, 2nd ed. Bloomington, IN: Indiana University Press.

Cassidy, L. (2012) Salford 7/District Six: The Use of Participatory Mapping and Material Artefacts, in Cultural Memory Projects, in Mapping Cultures: Place, Practice, Performance, edited by L. Roberts . New York: Palgrave Macmillan, pp. 181-198.

Casson, L. (1994) Travel in the Ancient World. Maryland: The John Hopkins University Press.

Certeau, M. de. (1988) The Practice of Everyday Life, trans. S. Rendell . Berkley: University of California Press.

Chaplin, S. and Holding, E. (1998) Consuming Architecture, in Consuming Architecture, edited by S. Chaplin and E. Holding . London: Architectural Design, pp. 7-9.

Childs, P. (2017) Places and Peoples: Nation and Region, in British Cultural Identities, 5th ed, edited by M. Storry and P. Childs . Abingdon, Oxon: Routledge, pp. 37-76.

Chronis, A. (2006) Heritage of the Senses: Collective Remembering as an Embodied Praxis.

Tourist Studies, 6 (3): 267-296.

Church, A. and Coles, T. (eds) (2007) Tourism, Power and Space. Abingdon, Oxon: Routledge. Clarke, T. (2002) Martin Heidegger. London: Routledge.

Classen, C. (1993) Worlds of Sense: Exploring the Senses in History and Across Cultures.

London: Routledge.

Clifford, J. (1997) Routes: Travel and Translation in the Late Twentieth Century. Cambridge, MA: Harvard University Press.

Clifford, J. (1988) The Predicament of Culture: Twentieth-Century Ethnography, Literature, and Art. Cambridge, MA: Harvard University Press.

Cloke, P. and Jones, O. (2001) Dwelling, Place, and Landscape: An Orchard in Somerset. Environment and Planning A, 33: 649-666.

Cohen, A. (ed) (1982) Belonging: The Experience of Culture, in Belonging. Identity and Social Organisation in British Rural Cultures, edited by A. P. Cohen . Manchester: Manchester University Press, pp. 1-17.

Cohen, E. (2012) Authenticity in Tourism Studies, in Critical Debates in Tourism, edited by V. Singh . Bristol: Channel View Publications, pp. 250-260.

Comaroff, J. and Comaroff, J. (1992) Ethnography and the Historical Imagination. Boulder, CO: Westview Press.

Cone, C. (1995) Crafting Selves: The Lives of Two Mayan Women. Annals of Tourism

Research, 22 (2): 314-327.

Connerton, P. (1989) How Societies Remember. Cambridge: Cambridge University Press.

Connor, W. (1993) Beyond Reason: The Nature of the Ethnonational Bond. Ethnic and Racial Studies, 16 (3): 373-389.

Copertino, D. (2014) The Tools of the Trade: The Materiality of Architecture in the Patrimonialization of 'Arab Houses' in Damascus. Journal of Material Culture, 19 (3): 327-351. Corbin, A. (1986) The Foul and the Fragrant: Odor and the French Social Imagination, trans. M. Kochan , R. Porter and C. Pendergast . Leamington Spa: Berg.

Cosgrove, D. (1997) Inhabiting Modern Landscape. Archaeological Dialogues, 4 (1): 23-28. Costas, J. and Grey, C. (2016) Secrecy at Work: The Hidden Architecture of Organizational Life. Stanford: Stanford University Press. 
Crane, S. (ed) (2000) Museums and Memory. Stanford: Stanford University Press.

Crane, S. (2011a) Memory, Distortion, and History in the Museum, in Museum Studies: An

Anthology of Contexts, edited by B. Carbonell , 2nd ed. Oxford: Wiley-Blackwell, pp. 303-316.

Crane, S. (2011b) The Conundrum of Ephemerality: Time, Memory, and Museums, in A

Companion to Museum Studies, edited by S. Macdonald . Chichester: Wiley-Blackwell, pp.

98-109.

Cresswell, T. (2006) On the Move: Mobility in the Modern Western World. Abingdon, Oxon:

Routledge.

Crick, M. (1994) Resplendent Sites, Discordant Voices: Sri Lankans and International Tourism.

Chur, Switzerland: Harwood.

Crossley, N. (2001) The Social Body: Habit, Identity and Desire. London: Sage.

Crouch, D. (2000) Places Around Us: Embodied Lay Geographies in Leisure and Tourism.

Leisure Studies, 19 (2): 63-76.

Crouch, D. (2010) Flirting With Space: Journeys and Creativity. Farnham: Ashgate.

Crouch, D. and Desforges, L. (2003) The Sensuous in the Tourist Encounter. Introduction: The

Power of the Body in Tourist Studies. Tourist Studies, 3 (1): 5-22.

Csordas, T. J. (1990) Embodiment as a Paradigm for Anthropology. Ethos, 18 (1): 5-47.

Csordas, T. J. (ed) (1994) Embodiment and Experience: The Existential Ground of Culture and

Self. Cambridge: Cambridge University Press.

Csordas, T. J. (1999) Embodiment and Cultural Phenomenology, in Perspectives on

Embodiment: The Intersections of Nature and Culture, edited by G. Weiss and H. Haber . New York: Routledge, pp. 143-162.

Culler, J. (1981) Semiotics of Tourism. American Journal of Semiotics, 1: 127-140.

Cwerner, S. , Kesselring, S. and Urry, J. (eds) (2009) Aeromobilities. London: Routledge.

Damasio, A. (2010) Self Comes to Mind: Constructing the Conscious Brain. New York:

Pantheon Books.

Dann, G. (1996) The Language of Tourism. Wallingford: CABI.

Dann, E. and Dann, G. (2011) Sightseeing for the Sightless and Soundless: Tourism

Experiences of the Dual Sensory Impaired: International Centre for Research and Study on

Tourism. Available at: www.ciret-tourism.com/.

Davies, N. (1999) The Isles: A History. London: Palgrave MacMillan.

Day, C. (2002) Spirit \& Place: Healing Our Environment: Healing Environment. Oxford:

Architectural.

Day, C. (2004) Places of the Soul: Architecture and Environmental Design as a Healing Art, 2nd ed. Oxford: Elsevier.

Dempsey, L. (2000) Scientific, Industrial, and Cultural Heritage: A Shared Approach. Ariadne, 22. Available at: www.ariadne.ac.uk/issue22/dempsey [accessed 3rd June 2016].

Desjarlais, R. (2015) Seared With Reality: Phenomenology Through Photography in Nepal, in Phenomenology in Anthropology: A Sense of Perspective, edited by K. Ram and C. Huston .

Bloomington, IN: Indiana University Press, pp. 197-223.

Devereux, C. and Carnegie, E. (2006) Pilgrimage: Journeying Beyond Self. Tourism Recreation Research, 31 (1): 47-56.

Dewey, J. (1958) Experience and Nature. New York: Dover Publications.

Dickinson, J. and Lumsdon, L. (2010) Slow Travel and Tourism. London: Earthscan.

Din, K. (1989) Islam and Tourism: Patterns, Issues, and Options. Annals of Tourism Research, 16 (4): 542-563.

Dodds, G. and Tavernor, R. (eds) (2002) Body and Building: Essays on the Changing Relations of Body and Architecture. Cambridge, MA: MIT Press.

Douglas, M. (1995) Forgotten Knowledge, in Shifting Contexts: Transformations in

Anthropological Knowledge, edited by M. Strathern . London: Routledge, pp. 13-29.

Douglas, M. (1996) Natural Symbols, 2nd ed. London: Routledge.

Dreyfus, D. L. (1991) Being-in-the-World: A Commentary on Heidegger's Being and Time,

Division I. Cambridge, MA: MIT Press.

Dreyfus, H. L. and Spinosa, C. (1997) Highway Bridges and Feasts: Heidegger and Borgmann on How to Affirm Technology. After Postmodernism Conference, Chicago: University of Chicago Press, 14-16th November 1997. Available at: www.focusing.org/apm_papers/dreyfus.html

[accessed 14th November 2011]. 
Dudley, S. , Barnes, A. , Binnie J. , Petrov, J. and Walklate, J. (eds) (2012) Narrating Objects, Collecting Stories. Abingdon, Oxon: Routledge.

Dudzinski, D. (2001) The Diving Bell Meets the Butterfly: On Identity Lost and Re-Membered. Theoretical Medicine and Bioethics, 22 (1): 33-46.

Duffy, K. , Hancock, P. and Tyler, M. (2017) Still Red Hot? Postfeminism and Gender

Subjectivity in the Airline Industry. Gender, Work and Organization, 24 (3): 260-273.

Easthope, A. (1992) What a Man's Gotta Do. The Masculine Myth in Popular Culture. New York: Routledge.

Eberhard, J. P. (2015) Architecture and Neuroscience: A Double Helix, in Mind in Architecture: Neuroscience, Embodiment, and the Future of Design, edited by S. Robinson and J. Pallasmaa . Cambridge, MA: The MIT Press, pp. 123-136.

Edensor, T. (1998) Tourists at the Taj: Performance and Meaning at a Symbolic Site. London: Routledge.

Edensor, T. (2002) National Identity, Popular Culture and Everyday Life. Oxford: Berg.

Edensor, T. (2008) Walking Through Ruins, in Ways of Walking, edited by T. Ingold and J. L. Vergunst Farnham: Ashgate, pp. 123-141.

Edensor, T. (2010) Walking in Rhythms: Place, Regulation, Style, and the Flow of Experience. Visual Studies, 25 (1): 69-79.

Edwards, P. (1989) Heidegger's Quest for Being. Philosophy, 64 (250): 437-470.

Edwards, S. (1998) The body as object versus the body as subject: the case of disability. Medicine. Health Care, and Philosophy, 1: 47-56.

Elastic City. (2017) Available at: www.elastic-city.org/thumbs-up [accessed 16th June 2017].

Eliade, M. (1959) The Sacred and the Profane: The Nature of Religion, trans. W. R. Trask . New York: Harcourt, Brace \& World Inc.

Elliott, A. and Urry, J. (2010) Mobile Lives. Abingdon, Oxon: Routledge.

Elsner, J. and Cardinal, R. (1994) The Cultures of Collecting. London: Reaktion.

Elton, G. R. (1974) England under the Tudors, 2nd ed. London: Methuen.

The Enchanted Forest. (2017) Available at: www.enchantedforest.org.uk/about-us/about [accessed 16th June 2017].

Eriksen, T. H. (2004) What is Anthropology? London: Pluto Press.

Erzen, J. (2011) Reading Mosques: Meaning and Architecture in Islam, in The Aesthetics of Architecture: Philosophical Investigations into the Art of Building, edited by D. Goldblatt and R.

Paden . Chichester: Wiley-Blackwell, The American Society for Aesthetics, pp. 125-131.

The Etches Collection. (2017) Tourist Brochure.

Fabian, J. (2014 [1983]) Time and the Other: How Anthropology Makes its Object, forward by

M. Bunzl . New York: Columbia University Press.

Fees, C. (1996) Tourism and the Politics of Authenticity in a North Cotswold Town, in The

Tourist Image: Myths and Myth Making in Tourism, edited by T. Selwyn . Chichester: Wiley-

Blackwell, pp. 121-146.

Fentress, J. (1992) Social Memory. Oxford: Blackwell.

Ferguson, J. M. (2014) Terminally Haunted: Aviation Ghosts, Hybrid Buddhist Practices, and Disaster Aversion Strategies Amongst Airport Workers in Myanmar and Thailand. The Asia Pacific Journal of Anthropology, 15 (1): 47-64.

Finley, C. (2004) Authenticating Dungeons, Whitewashing Castles: The Former Sites of the Slave Trade on the Ghanaian Coast, in Architecture and Tourism: Perception, Place and Performance, edited by D. M. Lasansky and B. McLaren . Oxford: Berg, pp. 109-126.

Foucault, M. (1977) Discipline and Punish: The Birth of the Prison. London: Penguin.

Franklin, A. (2004) Tourism as Ordering: Towards a New Ontology of Tourism. Tourist Studies, 4 (3): 277-301.

Franklin, A. (2007) The Problem With Tourism Theory, in The Critical Turn in Tourism Studies: Innovative Research Methodologies, edited by I. Ateljevic , A. Pritchard and N. Morgan . Oxford: Elsevier, pp. 131-148.

Franquesa, J. (2011) "We've Lost Our Bearings": Place, Tourism, and the Limits of the "Mobility Turn". Antipode, 43 (4): 1012-1033.

Fullagar, S. , Wilson, E. and Markwell, K. (2012) Starting Slow: Thinking Through Slow Mobilities and Experiences, in Slow Tourism: Experiences and Mobilities, edited by S. Fullagar, K. Markwell and E. Wilson . Bristol: Channel View Publications, pp. 1-8. 
Fuller, G. and Harley, R. (2004) Aviopolis: A Book About Airports. London: Black Dog

Publishing.

Geertz, C. (1973) The Interpretation of Cultures. New York: basic Books.

Gell, A. (1992a) The Technology of Enchantment and the Enchantment of Technology, in

Anthropology, Art and Aesthetics, edited by J. Coote and A. Sheldon . Oxford: Oxford University

Press, pp. 40-63.

Gell, A. (1992b) The Anthropology of Time: Cultural Constructions of Temporal Maps and

Images. Oxford: Berg.

Geurts, K. L. (2002) Culture and the Senses: Bodily Ways of Knowing in an African Community.

Berkeley: University of California Press.

Gieryn, T. (2002) What Buildings Do. Theory and Society, 31: 35-74.

Goffman, E. (1969) The Presentation of Self in Everyday Life. London: Penguin.

Goldblatt, D. and Paden, R. (eds) (2011) The Aesthetics of Architecture: Philosophical

Investigations into the Art of Building. Chichester: Wiley-Blackwell.

Gómez-Martín, M. B. (2005) Weather, Climate and Tourism: A Geographical Perspective.

Annals of Tourism Research, 32 (3): 571-591.

Gordon, A. (2008) Naked Airport: A Cultural History of the World's Most Revolutionary

Structure. Chicago: University of Chicago Press.

Gottdiener, M. (2001) Life in the Air: Surviving the New Culture of Air Travel. Lanham: Rowman \& Littlefield.

Graburn, N.H.H. (ed) (1976) Ethnic and Tourist Arts: Cultural Expressions From the Fourth World. Berkeley: University of California Press.

Graburn, N.H.H. (1983) The Anthropology of Tourism. Annals of Tourism Research, 10: 9-33.

Grange, J. (2000) Place, Body, Situation, in Dwelling, Place and Environment: Towards a

Phenomenology of Person and World, edited by D. Seamon and R. Mugerauer . Malabar, FL:

Krierger Publishing, pp. 71-84.

Gray, J. (1999) Open Spaces and Dewing Places: Being at Home on Hill Farms in the Scottish

Border. American Ethnologist, 26 (2): 440-460.

Gros, F. (2014) A Philosophy of Walking, trans. J. Howe . London: Verso.

Guichard-Anguis, S. and Moon, O. (eds) (2009) Japanese Tourism and Travel Culture. London:

Routledge, Taylor and Francis.

Hagen, J. (2010) Architecture, Symbolism, and Function: The Nazi Party's 'Forum of the

Movement'. Environment and Planning D: Society and Space, 28: 397-424.

Haigh, C. (1987) The Recent Historiography of the English Reformation, in The English

Reformation Revised, edited by C. Haig . Cambridge: Cambridge University Press, pp. 19-33.

Haigh, C. (1993) English Reformations: Religion, Politics and Society Under the Tudors. Oxford: Oxford University Press.

Halbwachs, M. (1992) On Collective Memory, ed. and trans. L. Coser . Chicago: University of Chicago Press.

Haldrup, M. and Larsen, J. (2006) Material Cultures of Tourism. Leisure Studies, 25 (3):

275-289.

Haldrup, M. and Larsen, J. (2010) Tourism, Performance and the Everyday, Consuming the Orient. Abingdon, Oxon: Routledge.

Hall, S. (1996) Introduction, Who Needs 'Identity?' in Questions of Cultural Identity, edited by S. Hall and P. du Guy . London: Sage, pp. 1-17.

Halliburton, D. (1981) Poetic Thinking: An Approach to Heidegger. Chicago: University of Chicago Press.

Harkin, M. (1995) Modernist Anthropology and Tourism of the Authentic. Annals of Tourism Research, 22 (3): 650-670.

Harley, R. (2011) Airportals: The Functional Significance of Stillness in the Junkspace of Airports, in Stillness in a Mobile World, edited by D. Bissell and G. Fuller . Abingdon, Oxon: Routledge, pp. 38-50.

Harries, K. (1993) Thoughts on a Non-Arbitrary Architecture, in Dwelling, Seeing, and Designing, edited by D. Seamon . Albany: State University of New York Press, pp. 41-59.

Harries, K. (1997) The Ethical Function of Architecture. Cambridge, MA: Massachusetts Institute of Technology.

Harries, K. (2011) Fantastic Architecture: Lessons of Laputa and the Unbearable lightness of our Architecture, in The Aesthetics of Architecture: Philosophical Investigations into the Art of 
Building, edited by D. Goldblatt and R. Paden . Chichester: Wiley-Blackwell, pp. 51-160. Harris, C. and O'Hanlon, M. (2013) The Future of the Ethnographic Museum. Anthropology Today, 29 (1): 8-12.

Harrison, J. (2003) Being a Tourist: Finding Meaning in Pleasure Travel. Vancouver: UBC Press.

Harrison, P. (2007) The Space Between Us: Opening Remarks on the Concept of Dwelling. Environment and Planning D, 25 (4): 625-647.

Harrison, R. , Byrne, S. and Clarke, A. (eds) (2013) Reassembling the Collection: Ethnographic Museums and Indigenous Agency. Santa Fe, New Mexico: SAR Press.

Haseler, S. (1996) The English Tribe: Identity, Nation and Europe. London: Palgrave MacMillan. Headrick, D. R. (1981) The Tools of Empire: Technology and European Imperialism in the Nineteenth Century. Oxford: Oxford University Press.

Heidegger, M. (1962) Being and Time, trans. J. Macquarrie and E. Robinson . Oxford: Blackwell.

Heidegger, M. (1982) On the Way to Language. New York: Harper \& Row. Heidegger, M. (2001 [1971]) Poetry, Language, Thought, trans. A. Hofstadter . New York: Harper Perennial Modern Classic.

Heidegger, M. (2008) Towards a Definition of Philosophy, trans. T. Sadler . London: Continuum. Henare, A. , Holbraad, M. and Wastell, S. (2007) Introduction: Thinking Through Things, in Thinking Through Things: Theorising Artefacts Ethnographically, edited by A. Henare, M. Holbraad and S. Wastell . Abingdon, Oxon: Routledge, pp. 1-31.

Henare, M. (2005) Museums, Anthropology and Imperial Exchange. Cambridge: Cambridge University Press.

Henderson, J. C. (2004) Tourism and British Colonial Heritage in Malaysia and Singapore, in Tourism and Postcolonialism: Contested Discourses, Identities and Representations, edited by C. M. Hall and H. Tucker . London: Routledge, pp. 113-125.

Henare, M. (2010) Islam and Tourism: Brunei, Indonesia, Malaysia and Singapore, in Tourism in the Muslim World, vol. 2, edited by N. Scott and J. Jafari . Bingley: Emerald Publishing, pp. 75-90.

Herzfeld, M. (1991) A Place in History: Social and Monumental Time in a Cretan Town. Princeton: Princeton University Press.

Herzfeld, M. (2001) Anthropology: Theoretical Practice in Culture and Society. Oxford: Blackwell.

Hever Castle and Gardens. (1966) Tourist Guide. The Times Publishing Company.

Hever Castle and Gardens. (1972) Tourist Guide. Norwich: Jarrold \& Sons.

Hever Castle and Gardens. (1995) Tourist Guide. Edenbridge.

Hever Castle and Gardens. (2008) Tourist Guide. Edenbridge: Hever Castle Ltd.

Hever Castle and Gardens. (2012) Tourist Guide: Hever Castle and Jigsaw Design and Publishing.

Hever Castle and Gardens. (2015) News Section. Available at:

www.hevercastle.co.uk/news/hever-castle-unveils-two-new-tudor-treasures/ [accessed 16th May 2017].

Hill, J. (2012) Weather Architecture. London: Routledge.

Hirsch, E. and O'Hanlon, M. (eds) (1995) The Anthropology of Landscape: Perspectives on Place and Space. Oxford: Clarendon Press.

Hoelscher, S. (2011) Heritage, in A Companion to Museum Studies, edited by S. Macdonald . Chichester: Wiley-Blackwell, pp. 198-218.

Hollinshead, K. (2007) 'Worldmaking' and the Transformation of Place and Culture: The Enlargement of Meethan's Analysis of Tourism and Global Change, in The Critical Turn in

Tourism Studies: Innovative Research Methodologies, edited by I. Ateljevic , A. Pritchard and N. Morgan . Oxford: Elsevier, pp. 165-193.

Hollinshead, K. , Ateljevic, I. and Ali, N. (2009) Worldmaking Agency - Worldmaking Authority:

The Sovereign Constitutive Role of Tourism. Tourism Geographies, 11 (4): 427-443.

Hooper-Greenhill, E. (1992) Museums and the Shaping of Knowledge. London: Routledge.

Hornborg, A-C. (2006) Visiting the Six Worlds: Shamanistic Journeys in Canadian Mi'Kmaq

Cosmology. Journal of American Folklore, 119 (473): 312-336. 
Horne, D. (1984) The Great Museum: The Re-Presentation of History. London: Pluto Press. Howard, P. J. (1994) The Nature of the Times Deceas'd. International Journal of Heritage Studies, 1 (1): 6-17.

Huberman, J. (2012) Ambivalent Encounters: Childhood, Tourism, and Social Change in Banaras, India. New Brunswick: Rutgers University Press.

Howes, D. (2005) Introduction: Empires of the Senses, in Empire of the Senses, edited by D. Howes . Oxford: Berg, 1-17.

Howes, D. and Classen, C. (2014) Ways of Sensing: Understanding the Senses in Society. Abingdon, Oxon: Routledge.

Husserl, E. (1970 [1936]) The Crisis of European Sciences and Transcendental

Phenomenology: An Introduction to Phenomenological Philosophy, trans. D. Carr . Evanston, IL: Northwestern University Press.

Ingold, T. (1992) Editorial. Man (N.S.), 27 (4): 693-696.

Ingold, T. (1993) The Temporality of the Landscape. World Archaeology, 25 (2): 152-174.

Ingold, T. (1995) Building, Dwelling, Living: How Animals and People Make Themselves at Home in the World, in Shifting Contexts: Transformations in Anthropological Knowledge, edited by M. Strathern . London: Routledge, pp. 57-80.

Ingold, T. (2003) From the Perception of Archaeology to the Anthropology of Perception: An Interview With Tim Ingold. Journal of Social Archaeology, 3 (1): 5-22.

Ingold, T. (2004) Culture on the Ground: The World Perceived Through the Feet. Journal of Material Culture, 9 (3): 315-340.

Ingold, T. (2005) Epilogue: Towards a Politics of Dwelling. Conservation \& Society, 3 (2): 501-508.

Ingold, T. (2007) Lines: A Brief History. London: Routledge.

Ingold, T. (2008) Bindings Against Boundaries: Entanglements of Life in an Open World.

Environment and Planning A, 40: 1796-1810.

Ingold, T. (2010) Ways of Mind-Walking: Reading, Writing, Painting. Visual Studies, 25 (1): 15-23.

Ingold, T. (2011a) Being Alive: Essays on Movement, Knowledge and Description. Abingdon, Oxon: Sage.

Ingold, T. (2011b [2000]) The Perception of the Environment: Essays on Livelihood, Dwelling and Skill, new preface ed. London: Routledge.

Ingold, T. (2013) Making: Anthropology, Archaeology, Art and Architecture. Abingdon, Oxon: Routledge.

Ingold, T. (2015) Life of Lines. London: Routledge.

Ingraham, C. (2008) White Weddings: Romancing Heterosexuality in Popular Culture, 2nd ed. London: Routledge.

Irving, A. (2005) Life Made Strange: An Essay on the Re-Inhabitation of Bodies and Landscapes, in The Qualities of Time: Anthropological Approaches, edited by W. James and D. Mills . Oxford: Berg, pp. 317-329.

Irving, A. (2013) Bridges: A New Sense of Scale. The Senses and Society, 8 (3): 290-313. Ives, E. (2005) The Life and Death of Anne Boleyn. Oxford: Wiley-Blackwell.

Jackson, J. B. (1994) A Sense of Place, a Sense of Time. New Haven: Yale University Press. Jackson, M. (1983) Knowledge of the Body. Man (NS), 18 (2): 327-345.

Jackson, M. (1989) Paths Toward a Clearing: Radical Empiricism and Ethnographic Enquiry. Bloomington, IN: Indiana University Press.

Jackson, M. (1995) At Home in the World. Durham, NC: Duke University Press.

Jackson, M. (2005) Existential Anthropology, Events, Exigencies and Effects. New York: Berghahn.

Jackson, M. (2007) Excursions. Durham, NC: Duke University Press.

Jackson, M. (2009) Where Thought Belongs: An Anthropological Critique of the Project of Philosophy. Anthropological Theory, 9 (3): 235-251.

Jamal, T. and Stronza, A. (2009) 'Dwelling' With Ecotourism in the Peruvian Amazon. Tourist Studies, 8 (3): 313-336.

James, W. and Mills, D. (eds) (2005) The Qualities of Time: Anthropological Approaches.

Oxford: Berg. 
Jameson, F. (1984) Postmodernism, or The Cultural Logic of Late Capitalism. New Left Review, 146 (July-August): 53-92.

Jones, N. (2001) The English Reformation: Religion and Cultural Adaptation. Oxford: WileyBlackwell.

Jones, O. and Cloke, P. (2002) Tree Cultures. Oxford: Berg.

Kadman, N. and Kabha, M. (2016) 'Home Tourism' Within a Conflict: Palestinian Visits to Houses and Villages Depopulated in 1948, in Tourism and Memories of Home: Migrants, Displaced People, Exiles, and Diasporic Communities, edited by S. Marschall . Bristol: Channel View Publications, pp. 88-112.

Kaplan, J. (2007) When the Astors Owned New York. London: Penguin.

Kaplan, F.E.S. (ed) (1994) Museums and the Making of "Ourselves": The Role of Objects in National Identity. London: Leicester University Press.

Kaplan, F.E.S. (2011) Making and Remaking National Identities, in A Companion to Museum Studies, edited by S. Macdonald . Chichester: Wiley-Blackwell, pp. 152-169.

Karp, I. and Kratz, C. (2014) Collecting, Exhibiting, and Interpreting: Museums as Midwives of Meaning. Museum Anthropology, 37 (1): 51-65.

Kavaler, L. (2000) The Astors: A Family Chronicle of Pomp and Power. London: iUniverse. Keane, W. (1995) The Spoken House: Text, Act, and Object in Eastern Indonesia. American Ethnologist, 22 (1): 102-124.

Keesing, R. (1987) Anthropology as Interpretive Quest. Current Anthropology, 28 (2): 161-176. Kensinger, K. (1995) How Real People Ought to Live: The Cashinahua of Eastern Peru.

Prospect Heights, IL: Waveland Press.

Kershaw, S. W. (1880) Famous Kentish Houses: Their History and Architecture. Paper read to the Architectural Association of London. High Holborn: Batsford.

Kesselring, S. (2009) Global Transfer Points: The Making of Airports in the Mobile Risk Society, in Aeromobilities, edited by S. Cwerner, S. Kesselring and J. Urry . London: Routledge, pp. 39-59.

Kim, H. and Jamal, T. (2007) Touristic Quest for Existential Authenticity. Annals of Tourism Research, 34 (1): 181-201.

Kirshenblatt-Gimblett, B. (1998) Destination Culture: Tourism, Museums and Heritage. Berkley, Los Angeles: University of California Press.

Kissell, J. L. (2001) Embodiment: An Introduction. Theoretical Medicine and Bioethics, 22 (1): $1-4$.

Knell, S. (ed) (2007) Museums in the Material World. Abingdon, Oxon: Routledge.

Knight, J. (1995) Tourist as Stranger? Explaining Tourism in Rural Japan. Social Anthropology, 3 (3): 219-234.

Kohn, E. (2013) How Forests Think: Toward an Anthropology of Beyond Human. Berkeley: University of California Press.

Kolas, A. (2008) Tourism and Tibetan Culture in Transition: A Place Called Shangrila. London: Routledge.

Kollewe, J. (2017) Inside the New Battersea Power Station. The Guardian, Saturday, 13th May. Available at: www.theguardian.com/business/2017/may/13/inside-the-new-battersea-power-

station [accessed 26th June 2017].

Kraftl, P. and Adey, P. (2008) Architecture/Affect/Inhabitation: Geographies of Being-In

Buildings. Annals of the Association of American Geographers, 98 (1): 213-231.

Kuper, H. (1972) The Language of Sites in the Politics of Space. American Anthropologist, 74

(3): 411-425.

Lagerkvist, A. (2007) Gazing at Pudong - "With a Drink in Your Hand": Time Travel, Mediation, and Multisensuous Immersion in the Future City of Shanghai. Senses \& Society, 2 (2): 155-172.

Lakoff, G. and Johnson, M. (1980) Metaphors We Live By. Chicago: Chicago University Press. Lakoff, G. and Johnson, M. (1999) Philosophy in the Flesh: The Embodied Mind and Its Challenge to Western Thought. New York: Basic Books.

Lambek, M. (1998) Body and Mind in Mind, Body and Mind in Body: Some Anthropological Interventions in a Long Conversation, in Bodies and Persons: Comparative Perspectives From Africa and Melanesia, edited by M. Lambek and A. Strathern . Cambridge: Cambridge University Press, pp. 103-124. 
Lande, B. (2007) Breathing Like a Soldier: Culture Incarnate, in Embodying Sociology: Retrospect, Progress and Prospects, edited by C. Shilling . Oxford: Wiley-Blackwell, pp. 95-108.

Larsen, J. (2008) De-Exoticizing Tourist Travel: Everyday Life and Sociality on the Move. Leisure Studies, 27 (1): 21-34.

Larsen, J. and Urry, J. (2011) Gazing and Performing. Environment and Planning D: Society and Space, 29: 1110-1125.

Lau, R.W.J. (2010) Revisiting Authenticity. Annals of Tourism Research, 37 (2): 478-498. Lazarin, M. (2008) Temporal Architecture: Poetic Dwelling in Japanese Buildings. Architecture and Phenomenology, (Autumn): 97-112.

Leach, N. (2000) Forget Heidegger. Scroope: Cambridge Architecture Journal, 12: 28-32. Lefebvre, H. (1991) The Production of Space, trans. D. Nicolson-Smith . Oxford: WileyBlackwell.

Lennon, J. and Foley, M. (2000) Dark Tourism: The Attraction of Death and Disaster. London: Continuum.

Lennon, J. and Mitchell, M. (2007) Dark Tourism: The Role of Sites of Death in Tourism, in Remember Me: Constructing Immortality: Beliefs on Immortality, Life and Death, edited by M. Mitchell . London: Routledge, pp. 167-178.

Levell, N. (2000) Oriental Visions: Exhibitions, Travel and Collecting in the Victorian Age. London: Horniman Museum.

Levi-Strauss, C. (1972) The Savage Mind. London: Weidenfeld \& Nicolson.

Levi-Strauss, C. (1983) The Way of the Masks, trans. S. Modelski . London: Jonathan Cape.

Levi-Strauss, C. (1986) The Raw and the Cooked: Introduction to a Science of Mythology, trans. $\mathrm{J}$ and D. Weightman . Harmondsworth: Penguin.

Levi-Strauss, C. (1995) Myth and Meaning. Cracking the Code of Culture. New York: Schocken Books.

Light, D. (2000) Gazing on Communism: Heritage Tourism and Post-Communist Identities in Germany, Hungary and Romania. Tourist Geographies, 2 (2): 157-176.

Lloyd, J. (2002) Departing Sovereignty. Borderlands e-Journal, 1 (2): 1-11. Available at: http://www.borderlands.net.au/vol1no2_2002/lloyd_departing.html [accessed 18th January 2015].

Lloyd, J. (2003) Dwelltime: Airport Technology, Travel, and Consumption. Space \& Culture, 6 (2): 93-109.

Lloyd, G.E.R. (2011) Humanity Between Gods and Beasts? Ontologies in Question. Journal of the Royal Anthropological Institute (NS), 17: 829-845.

Lobell, J. (1979) Between Silence and Light: Spirit in the Architecture of Louis I. Kahn. Boston, MA: Shambhala Publications.

Logan, W. (2012) Air: The Restless Shaper of the World. New York: W. W. Norton \& Company. London Transport Museum (2016) Available at: www.Itmuseum.co.uk/collections/museumcollection/collecting-policy [accessed 15th April 2016].

Lovegrove, K. (2000) Airline: Identity, Design and Culture. London: Laurence King Publishing. Lowenthal, D. (1961) Geography, Experience, and Imagination: Towards a Geographical Epistemology. Annals of the Association of American Geographers, 51 (3): 241-260.

Lowenthal, D. (1998) The Heritage Crusade and the Spoils of History. Cambridge: Cambridge University Press.

Lund, K. A. and Jóhannesson, G. T. (2016) Earthly Substances and Narrative Encounters:

Poetics of Making a Tourism Destination. Cultural Geographies, 23 (4): 653-669.

Lury, C. (1997) The Objects of Travel, in Touring Cultures: Transformations of Travel and

Theory, edited by C. Rojek and J. Urry . London: Routledge, pp. 75-95.

Lytton, U. (1989) Aspects of Dual Symbolic Classification: Right and Left in a Japanese KyūDōjō. Asian Folklore Studies, 48: 277-291.

Macdonald, S. (ed) (1998) The Politics of Display: Museums, Science and Culture. London: Routledge.

Macdonald, S. (2006) Undesirable Heritage: Fascist Material Culture and Historical Consciousness in Nuremberg. International Journal of Heritage Studies, 12 (1): 9-28.

Macdonald, S. (2011) Collecting practices, in A Companion to Museum Studies, edited by S. Macdonald . Chichester: Wiley-Blackwell, pp. 81-97. 
Macdonald, S. (2013) Memorylands: Heritage and Identity in Europe Today. Abingdon, Oxon: Routledge.

MacGregor, N. (2004) Oi, Hands Off Our Marbles! The Sunday Times News Review, 18th January, 7.

MacGregor, N. (2012) A History of the World in 100 Objects. London: Penguin.

Machlis, G. and Burch, W. (1983) Relations Between Strangers: Cycles of Structure and

Meaning in Tourist Systems. The Sociological Review, 31 (4): 666-692.

Macleod, D. and Carrier, J. (eds) (2010) Tourism, Power and Culture: Anthropological Insights. Bristol: Channel View Publications.

Macnaghten, P. and Urry, J. (2000) Bodies in the Wood. Body \& Society, 6 (3-4): 166-182. MacPhee, G. (2002) The Architecture of the Invisible: Technology and Urban Visual Culture. London: Continuum.

Macpherson, H. (2009) Articulating Blind Touch: Thinking Through the Feet. The Senses and Society, 4 (2): 179-194.

Malkki, L. (1995) Purity in Exile: Violence, Memory, and National Cosmology Among Hutu Refugees in Tanzania. Chicago: University of Chicago Press.

Mallgrave, F. (2010) The Architect's Brain: Neuroscience, Creativity and Architecture.

Chichester: Wiley-Blackwell.

Malpas, J. (2008) Heidegger's Topology: Being, Place, World. Cambridge, MA: Massachusetts Institute of Technology Press.

Markwell, K. (2015) Birds, Beats and Tourists: Human-Animal Relationships in Tourism, in Animals and Tourism: Understanding Diverse Relationships, edited by K. Markwell . Bristol: Channel View Publications, pp. 1-23.

Marsh, R. and Hudson, J. (2014) Locked in: One Man's Miraculous Escape From the Terrifying Confines of Locked-in Syndrome. London: Piatkus.

Martin, A. M. (2016) Introduction: The Sensory in Russian and Soviet History, in Russian History Through the Senses: From 1700 to the Present, edited by M. P. Romaniello and T. Starks . London: Bloomsbury, pp. 1-19.

Martin, E. (1992) The End of the Body? American Ethnologist, 19 (1): 121-129.

Massey, D. (2005) For Space. London: Sage.

Matless, D. (1998) Landscape and Englishness. London: Reaktion Books.

Matteucci, X. (2014) Forms of Body Usage in Tourists' Experiences of Flamenco. Annals of Tourism Research, 46: 29-43.

Mauss, M. (1979) Sociology and Psychology: Essays by Marcel Mauss. London: Routledge. McLaren, B. (2006) Architecture and Tourism in Italian Colonial Libya. Seattle: University of Washington Press.

Medina, L. K. (2003) Commoditizing Culture: Tourism and Maya Identity. Annals of Tourism Research, 30 (2): 353-368.

Melhuish, C. (2005) Towards a Phenomenology of the Concrete Megastructure. Journal of Material Culture, 10 (1): 5-29.

Merchant, S. (2011) Negotiating Underwater Space: The Sensorium, the Body and the Practice of Scuba-Diving. Tourist Studies, 11 (3): 215-234.

Merleau-Ponty, M. (2002 [1945]) Phenomenology of Perception. London: Routledge.

Miller, D. (1998a) A Theory of Shopping. London: Sage.

Miller, D. (ed) (1998b) Material Cultures: Why Some Things Matter. London: Sage.

Miller, D. (2007) Stone Age or Plastic Age? Archaeological Dialogues, 14 (1): 23-27.

Molz, J. G. (2004) Playing Online and Between the Lines: Round-the-World Websites as Virtual Places to Play, in Tourism Mobilities: Places to Play, Places in Play, edited by M. Sheller and J. Urry . London: Routledge, pp. 169-180.

Molz, J. G. (2012) Travel Connections: Tourism, Technology and Togetherness in a Mobile World. Abingdon, Oxon: Routledge.

Morosan, C. and Fesenmaier, D. R. (2007) A Conceptual Framework of Persuasive Architecture of Tourism Websites: Propositions and Implications, in Information and Communication Technologies in Tourism. Proceedings of the International Conference in Ljubljana, Slovenia, edited by M. Sigala, L. Mich and J. Murphy . New York: Springer Ein, pp. 243-254. Available at: https://link.springer.com/book/10.1007/978-3-211-69566-1. 
Morphy, H. (1995) Landscape and the Reproduction of the Ancestral Past, in The Anthropology of Landscape: Perspectives on Place and Space, edited by E. Hirsch and M. O'Hanlon . Oxford: Clarendon Press, pp. 184-209.

Morris, B. (1997) In Defence of Realism and Truth: Critical Reflections on the Anthropological Followers of Heidegger. Critique of Anthropology, 17 (3): 313-340.

Moutu, A. (2007) Collection as a Way of Being, in Thinking Through Things: Theorising Artefacts Ethnographically, edited by A. Henare, M. Holbraad and S. Wastell . Abingdon, Oxon: Routledge, pp. 93-112.

Msila, V. (2013) The Liberatory Function of a Museum: The Case of New Brighton's Red Location Museum. Anthropologist, 15 (2): 209-218.

Munn, N. (1992) A Cultural Anthropology of Time: A Critical Essay. Annual Review of Anthropology, 23: 91-123.

Mugerauer, R. (1993) Toward an Architectural Vocabulary: The Porch as Between, in Dwelling, Seeing, and Designing: Toward a Phenomenological Ecology, edited by D. Seamon . Albany: State University of New York Press, pp. 103-128.

Mukhopadhyay, B. (2006) Crossing the Howrah Bridge: Calcutta, Filth and Dwelling - Forms, Fragments, Phantasms. Theory, Culture and Society, 27 (7-8): 221-241.

Mullen, R. and Munson, J. (2009) The Smell of the Continent. London: Palgrave MacMillan. Museum of Science, Boston (2015) Available at: www.mos.org/planetarium/explore-the-solarsystem [accessed 22nd October 2015].

Myers, A. and Moshenska, G. (eds) (2011) Archaeologies of Internment. New York: Springer. Nadel-Klein, J. (2003) Fishing for Heritage: Modernity and Loss Along the Scottish Coast. Oxford: Berg.

Nash, M. (2013) Brides N' Bumps: A Critical Look at Bridal Pregnancy Identities, Maternity Wedding Dresses, and Post-Feminism. Feminist Media Studies, 13 (4): 593-612.

Neuman, E. (2016) Shoah Presence: Architectural Representations of the Holocaust. Abingdon, Oxon: Routledge. Available at: news24: www.news24.com/SouthAfrica/News/PE-residentsforce-anti-apartheid-museum-to-close-20140731 [accessed 8th April 2016].

Nielsen, N. K. (2003) New Year in ... On Nationalism and Sensuous Holidays in Finland. Tourist Studies, 3 (1): 83-98.

Nora, P. (1989) Between Memory and History. Les Lieux de Mémoire: Representations, trans. M. Roudebush , 26: 7-24.

Norberg-Schulz, C. (1980) Genius Loci: Towards a Phenomenology of Architecture. London: Academy Editions.

Notar, B. (2007) Displacing Desire: Travel and Popular Culture in China. Honolulu: University of Hawaii Press.

Noy, C. (2004) This Trip Really Changed Me: Backpacker's Narratives of Self-Change. Annals of Tourism Research, 31 (1): 78-102.

Nunez, T. (1963) Tourism, Tradition and Acculturation: Weekendismo in a Mexican Village. Ethnology, 2 (3): 347-352.

Nyíri, P. (2006) Scenic Spots: Chinese Tourism, the State, and Cultural Authority. Seattle: University of Washington Press.

Obrador-Pons, P. (2003) Being-On-Holiday: Tourist Dwelling, Bodies and Place. Tourist

Studies, 31 (1): 47-66.

Obrador-Pons, P. (2007) A Haptic Geography of the Beach: Naked Bodies, Vision and Touch.

Social \& Cultural Geography, 8 (1): 123-141.

Okely, J. (1983) Changing Cultures: The Traveller-Gypsies. New York: Cambridge University Press.

Okhovat, H. (2010) A Study on Religious Tourism Industry Management Case Study: Islamic Republic of Iran. International Journal of Academic Research, 2 (5): 302-307. Available at: www.jjar.lit.azl.

O'Regan, M. (2016) A Backpacker Habitus: The Body and Dress, Embodiment and the Self. Annals of Leisure Research, 19 (3): 329-346.

O'Rourke, D. (Producer and Director) (1987) Cannibal Tours [Videotape]. Canberra: O'Rourke and Associates.

Østergaard, J. and Christensen, R. (2010) Walking Towards Oneself: The Authentication of Place and Self, in Re-Investing Authenticity: Tourism, Place and Emotions, edited by B. T. Knudsen and A. M. Waade . Bristol: Channel View, pp. 241-253. 
Ousby, I. (2002) The Englishman's England: Taste, Travel and the Rise of Tourism. London: Pimlico.

Pallasmaa, J. (2005) The Eyes of the Skin: Architecture and the Senses. Chichester: WileyBlackwell.

Pallasmaa, J. (2012) The Eyes of the Skin: Architecture and the Senses, 3rd ed. Chichester: Wiley-Blackwell.

Palmer, C. (1994) Tourism and Colonialism: The Experience of the Bahamas. Annals of Tourism Research, 21 (4): 792-812.

Palmer, C. (1998) Heritage Tourism and English National Identity. Unpublished PhD Thesis, University of North, London.

Palmer, C. (2003) Touring Churchill's England: Rituals of Kinship and Belonging. Annals of Tourism Research, 30 (2): 426-445.

Palmer, C. (2004) 'More Than Just a Game': The Consequences of Golf Tourism, in Sport Tourism: Interrelationships, Impacts and Issues, edited by B. W. Ritchie and D. Adair .

Clevedon: Channel View publications, pp. 117-134.

Palmer, C. (2005) An Ethnography of Englishness: Experiencing Identity Through Tourism. Annals of Tourism Research, 32: 7-27.

Palmer, C. (2009) Reflections on the Practice of Ethnography in Heritage Tourism, in Heritage Studies: Methods and Approaches, edited by M-L. S. Sørensen and J. Carman . London: Routledge, pp. 123-139.

Palmer, C. and Lester, J. (2007) Stalking the Cannibals: Photographic Behaviour on the Sepik River. Tourist Studies, 7 (1): 83-106.

Palmer, C. , Cooper, J. and Burns, P. (2010) Culture, Identity and Belonging in the Culinary Underbelly. International Journal of Culture, Tourism and Hospitality Research, 4 (4): 311-326. Parker Pearson, M. and Richards, C. (eds) (1997) Architecture and Order: Approaches to Social Space. London: Routledge.

Pearman, H. (2004) Airports: A Century of Architecture. London: Laurence King Publishing. Pearman, H. (2008) The Onward Journey. The Architectural Review, 224 (1338): 70-73.

Pearce, S. (ed) (1994) Interpreting Objects and Collections. London: Routledge.

Pernecky, T. (2010) The Being of Tourism. The Journal of Tourism and Peace Research, 1 (1): 1-15.

Pernecky, T. and Jamal, T. (2010) (Hermeneutic) Phenomenology in Tourism Studies. Annals of Tourism Research, 37 (4): 1055-1075.

Philipse, H. (1998) Heidegger's Philosophy of Being: A Critical Interpretation. Princeton:

Princeton University Press.

Picard, D. (2011) Tourism, Magic and Modernity: Cultivating the Human Garden: New York and Oxford: Berghahn.

Picard, D. and Di Giovine, M. (2014) Introduction: Through Other Worlds, in Tourism and the Power of Otherness: Seductions of Difference, edited by D. Picard and M. Di Giovine . Bristol: Channel View publications, pp. 1-28.

Picard, D. and Robinson, M. (eds) (2012) Emotion in Motion: Tourism, Affect and Transformation. Abingdon, Oxon: Routledge.

Picken, F. (2010) Tourism, Design and Controversy: Calling on Non-Humans to Explain Ourselves. Tourist Studies, 10 (3): 245-263.

Pink, S. (2008) Sense and Sensibility: The Case of the Slow City Movement. Local Environment, 13 (2): 95-106.

Pint, K. (2013) If These Walls Could Walk: Architecture as a Deformative Scenography of the Past, in Performing Memory in Art and Popular Culture, edited by L. Plate and A. Smelik . Abingdon, Oxon: Routledge, pp. 123-134.

Polt, R. (1999) Heidegger: An Introduction. Abingdon, Oxon: Routledge.

Powles, J. (2005) Embodied Memories: Displacements in Time and Space, in The Qualities of Time: Anthropological Approaches, edited by W. James and D. Mills . Oxford: Berg, pp. 331-347.

Pretes, M. (2003) Tourism and Nationalism. Annals of Tourism Research, 30 (1): 125-142. Preziosi, D. and Farago, C. (eds) (2004a) Grasping the World: The Idea of the Museum. Aldershot: Ashgate.

Preziosi, D. and Farago, C. (eds) (2004b) General Introduction: What Are Museums For? in Grasping the World: The Idea of the Museum, edited by D. Preziosi and C. Farago . Aldershot: 
Ashgate, pp. 1-9.

Pritchard, A. and Morgan, N. (2006) Hotel Babylon? Exploring Hotels as Liminal Sites of Transition and Transgression. Tourism Management, 27: 762-772.

Prussin, L. (1995) African Nomadic Architecture: Space, Place and Gender. Washington, DC: Smithsonian Institution Press.

Rabinow, P. (2008) Marking Time: On the Anthropology of the Contemporary. Princeton:

Princeton University Press.

Rakić, T. and Chambers, D. (2012) Rethinking the Consumption of Places. Annals of Tourism Research, 39 (3): 1612-1633.

Rassool, C. (2006) Making the District Six Museum in Cape Town. Museum International, 58 (1-2): 9-18.

Reisinger, Y. and Steiner, C. J. (2006) Reconceptualizing Object Authenticity. Annals of Tourism Research, 33: 65-86.

Ren, C. (2011) Non-Human Agency, Radical Ontology and Tourism Realities. Annals of Tourism Research, 38 (3): 858-881.

Richards, V. , Pritchard, A. and Morgan, N. (2010) (Re)envisioning Tourism and Visual Impairment. Annals of Tourism Research, 37 (4): 1097-1116.

Richardson, M. (1982) Being-in-the-Market Versus Being-in-the-Plaza: Material Culture and the Construction of Social Reality in Spanish America. American Ethnologist, 9 (2): 421-436.

Rickley-Boyd, J. M. , Knudsen, D. C. , Braverman, L. C. and Metro-Roland, M. M. (2014) Tourism, Performance, and Place: A Geographic Perspective. Farnham: Ashgate.

Robinson, H. (2009) Digital Heritage: Remembering Things Differently: Museums, Libraries and Archives as Memory Institutions and the Implications for Convergence. Museum Management and Curatorship, 27 (4): 431-429.

Robinson, M. and Phipps, A. (2003) Editorial. Worlds Passing by: Journeys of Culture and Cultural Journeys. Journal of Tourism and Cultural Change, 1 (1): 1-10.

Rodaway, P. (1994) Sensuous Geographies: body, sense and place. London: Routledge. Rodger, J. (2015) The Hero Building: An Architecture of Scottish National Identity. Farnham: Ashgate.

Romaniello, M. P. and Starks, T. (eds) (2016) Russian History Through the Senses: From 1700 to the Present. London: Bloomsbury.

Rose, M. (2012) Dwelling as Marking and Claiming. Environment and Planning D: Society and Space, 30: 757-771.

Rosler, M. (1997) In the Place of the Public: Observations of a Frequent Flyer, in Airport: The Most Important Buildings of the Twentieth-Century, edited by S. Bode and J. Millar . London: The Photographer's Gallery, pp. 89-109.

Rosman, A. and Rubel, P. (1998) Why They Collected: The History of Artifact Collecting in New Ireland. Museum Anthropology, 22 (2): 35-49.

Rovelli, C. (2015) Seven Brief Lessons on Physics, trans. S. Carnell and E. Segre . London: Penguin.

Ryan, C. (1997) 'The Time of Our Lives' or Time for Our Lives: An Examination of Time in Holidaying, in The Tourist Experience: A New Introduction, edited by C. Ryan . London: Cassell, pp. 194-205.

Ryan, C. and Crotts, J. (1997) Carving and Tourism: A Maori Perspective. Annals of Tourism Research, 24 (4): 898-918.

Ryan, C. and Huimin, G. (eds) (2009) Tourism in China, Destination, Cultures and

Communities. New York: Routledge.

Said, E. (2000) Invention, Memory and Place. Critical Inquiry, 26: 175-192.

Saldaña, J. (2006) This Is Not a Performance Text. Qualitative Inquiry, 12 (6): 1091-1098.

Samuel, R. (1994) Theatres of Memory. London: Verso.

Sanad, H. , Kassem, A. and Scott, N. (2010) Tourism and Islamic Law, in Tourism in the Muslim World, vol. 2, edited by N. Scott and J. Jafari . Bingley: Emerald Publishing, pp. 17-30.

Sandström, K. (2007) The Lived Body - Experiences From Adults With Cerebral Palsy. Clinical Rehabilitation, 21: 432-441.

Scannell, P. (2014) Television and the Meaning of Life. Cambridge: Polity Press.

Scarles, C. (2009) Becoming Tourist: Renegotiating the Visual in the Tourist Experience.

Environment and Planning D: Society and Space, 27: 465-488. 
Scarles, C. (2012) Eliciting Embodied Knowledge and Response: Respondent-Led Photography and Autoethnography, in An Introduction to Visual Research Methods in Tourism, edited by T. Rakić and D. Chambers . Abingdon, Oxon: Routledge, pp. 70-91.

Schama, S. (2004) Landscape and Memory. London: Harper Perennial.

Scheper-Hughes, N. and Lock, M. (1987) The Mindful Body: A Prolegomenon to Future Work in Medical Anthropology. Medical Anthropology Quarterly (NS), 1 (1): 6-41.

Schrock, D. and Boyd, E. (2006) Reflexive Transembodiment, in Body/Embodiment: Symbolic Interaction and the Sociology of the body, edited by D. Waskul and P. Vannini . Abingdon, Oxon: Ashgate, Routledge, pp. 51-66.

Schutz, A. (1944) The Stranger: An Essay in Social Psychology. American Journal of Sociology, 49 (6): 499-507.

Schwarz, O. (2013) What Should Nature Sound Like? Techniques of Engagement With Nature Sites and Sonic Preferences of Israeli Visitors. Annals of Tourism Research, 42: 382-401.

Scott, J. and Selwyn, T. (2010) Introduction: Thinking Through Tourism - Framing the Volume, in Thinking Through Tourism, edited by J. Scott and T. Selwyn . Oxford: Berg, pp. 1-25.

Seamon, D. (1979) A Geography of the Lifeworld. London: Croom Helm.

Seamon, D. (2000) A Way of Seeing People and Place: Phenomenology in Environment-

Behavior Research, in Theoretical Perspectives in Environment-Behavior Research, edited by S. Wapner, J. Demick , T. Yamamoto and H. Minami . New York: Kluwer Academic, Plenum Publishers, pp. 157-178.

Selänniemi, T. (2003) On Holiday in the Liminoid Playground: Place, Time, and Self, in Sex and Tourism: Journeys of Romance, Love, and Lust, edited by T. Bauer and B. McKercher . New York: The Haworth Press, pp. 29-31.

Selwyn, T. (1995) Landscapes of Liberation and Imprisonment: Towards an Anthropology of the Israeli Landscape, in The Anthropology of Landscape: Perspectives on Place and Space, edited by E. Hirsch and M. O'Hanlon Oxford: Clarendon Press, pp. 114-134.

Selwyn, T. (1996) The Tourist Image: Myths and Myth Making in Tourism. Chichester: WileyBlackwell

Selwyn, T. (2007) The Political Economy of Enchantment: Formations in the Anthropology of Tourism. Suomen Antropologi: Journal of the Finnish Anthropological Society, 32 (2): 48-70. Selwyn, T. (2010) The Tourist as Juggler in a Hall of Mirrors: Looking Through Images at the Self, in Culture, Heritage and Representation: Perspectives on Visuality and the Past, edited by E. Waterton and S. Watson . Farnham: Ashgate, pp. 195-214.

Selwyn, T. (2013) The Self in the World and the World in the Self: The SOAS MA in Anthropology of Travel, Tourism, and Pilgrimage. Journal of Tourism Challenges and Trends, 6 (2): 95-125.

Seremetakis, C. N. (1996a) Contexts, in The Senses Still: Perception and Memory as Material Culture in Modernity, edited by C. N. Seremetakis . Chicago: University of Chicago Press, pp. vii-xi.

Seremetakis, C. N. (1996b) The Memory of the Senses, Part I: Marks of the Transitory, in The Senses Still: Perception and Memory as Material Culture in Modernity, edited by C. N.

Seremetakis . Chicago: University of Chicago Press, pp. 1-18.

Seremetakis, C. N. (1996c) The Memory of the Senses, Part II: Still Acts, in The Senses Still:

Perception and Memory as Material Culture in Modernity, edited by C. N. Seremetakis .

Chicago: University of Chicago Press, pp. 23-44.

Serres, M. (1995) Angels: A Modern Myth, trans. F. Cowper . Paris: Flammarion.

Serres, M. (2008) The Five Senses: A Philosophy of Mingled Bodies, trans. M. Sankey and P. Cowley . London: Continuum.

Shannon, K. (2009) Evolving Tourist Topographies: The Case of Hue, Vietnam, in Travel, Space, Architecture, edited by J. Traganou and M. Mitrašinović . Franham: Ashgate, pp. 230-250.

Sharr, A. (2007) Heidegger for Architects. London: Routledge.

Shaw, G. B. (1946) Saint Joan. London: Penguin.

Sheffer, G. (2006) Diaspora Politics: At Home Abroad. Cambridge: Cambridge University Press. Sheller, M. and Urry, J. (eds) (2004) Tourism Mobilities: Places to Play, Places in Play. London: Routledge.

Sheller, M. and Urry, J. (2006) The New Mobilities Paradigm. Environment and Planning A, 38: 207-226. 
Shelton, A. (2011) Museums and Anthropologies: Practices and Narratives, in A Companion to Museum Studies, edited by S. Macdonald . Chichester: Wiley-Blackwell, pp. 64-80.

Shepherd, R. (2015) Why Heidegger Did Not Travel: Existential Angst, Authenticity, and Tourist Experiences. Annals of Tourism Research, 52: 60-71.

Shilling, C. (2003) The Body and Social Theory, 2nd ed. London: Sage.

Short, J. R. (1991) Imagined Country: Environment, Culture and Society. London: Routledge.

Singh, T. V. (ed) (2012) Critical Debates in Tourism. Bristol: Channel View Publications.

Sinha, C. , Sinha, V. , Zinken, J. and Sampaio, W. (2011) When Time Is Not Space: The Social and Linguistic Construction of Time Intervals and Temporal Event Relations in an Amazonian Culture. Language and Cognition, 3 (1): 137-169.

Sinha, V. , Sinha, C. , Sampaio, W. and Zinken, J. (2012) Even-Based Time Intervals in Amazonian Culture, in Space and Time in Languages and Cultures: Language, Culture and Cognition, edited by L. Filipović and K. Jaszczolt . Amsterdam: John Benjamins Publishing, pp. 15-35.

Skinner, J. (2007) Emotional Baggage: The Meaning/Feeling Debate Amongst Tourists, in The Emotions: A Cultural Reader, edited by H. Wulff . Oxford: Berg, pp. 339-353.

Skinner, J. (2016) Walking the Falls: Dark Tourism and the Significance of Movement on the Political Tour of West Belfast. Tourist Studies, 16 (1): 23-39.

Skinner, J. and Theodossopoulos, D. (2011) Introduction: The Play of Expectation in Tourism, in Great Expectations: Imagination and Anticipation in Tourism, edited by J. Skinner and D. Theodossopoulos . London: Berghahn, pp. 1-26.

Small, J. (2016) The Experience of Time in Long-Term Travel. Tourism Geographies, 18 (4): 341-358.

Small, J. and Darcy, S. (2011) Understanding Tourist Experience Through Embodiment, in Accessible Tourism: Concepts and Issues, edited by D. Buhalis and S. Darcy . Bristol: Channel View publications, pp. 73-97.

Small, J. , Packer, T. and Darcy, S. (2012) The Embodied Tourist Experiences of People With Vision Impairment: Management Implications Beyond the Visual Gaze. Tourism Management, 33: 941-950.

Smith, A. (1991) National Identity. London: Penguin.

Smith, M. and Kelly, C. (2006) Holistic Tourism: Journeys of the Self? Tourism Recreation Research, 31 (1): 15-24.

Solnit, R. (2002) Wanderlust: A History of Walking. London: Verso.

Somerset, A. (1997) Elizabeth 1. London: Phoenix, Orion Books.

Sommer, A-L. (2010) Nature Choreographed, in The Humanities in Architectural Design: A Contemporary and Historical Perspective, edited by J. Lomholt, N. Temple and R. Tobe . Abingdon, Oxon: Routledge, pp. 226-236.

Starkey, D. (1998) Henry V111. Channel 4 Television, 29th March.

Starkey, D. (2001) Elizabeth: Apprenticeship. London: Vintage Books.

Stein, R. (2008) Itineraries in Conflict: Israelis, Palestinians and the Political Lives of Tourism. Durham, NC: Duke University Press.

Steiner, G. (1989) Martin Heidegger, with a new introduction. Chicago: University of Chicago Press.

Steiner, C. J. and Reisinger, Y. (2006a) Understanding Existential Authenticity. Annals of Tourism Research, 33 (2): 299-318.

Steiner, C. J. and Reisinger, Y. (2006b) Ringing the Fourfold: A Philosophical Framework for Thinking About Wellness Tourism. Tourism Recreation Research, 31 (1): 5-14.

Stephenson, M. (2004) Tourism, Racism and the UK Afro-Caribbean Diaspora, in Tourism, Diasporas and Space, edited by T. Coles and D. J. Timothy . London: Routledge, pp. 62-77. Stocking, G. (1987) Victorian Anthropology. Oxford: Maxwell Macmillan.

Stokes-Rees, E. (2013) Making Sense of a Mélange: Representing Cultural Citizenship in Singapore's Asian Civilisations Museum. Museum Anthropology, 36 (1): 33-50.

Stoller, P. (1984) Sound in Songhay Cultural Experience. American Ethnologist, 11 (3): 559-570.

Stoller, P. (1989) The Taste of Ethnographic Things: The Senses in Anthropology. Philadelphia: University of Pennsylvania Press.

Strathern, M. (1982) The Village as an Idea: Constructs of Village-Ness in Elmdon, Essex, in Belonging: Identity and Social Organisation in British Rural Cultures, edited by A. P. Cohen . 
Manchester: Manchester University Press, pp. 247-277.

Strathern, M. (1992) After Nature: English Kinship in the Late Twentieth Century. Manchester: Manchester University Press.

Stretch, E. (2014) Floods Stormageddon - An Englishman's Home Is His Castle as Builder

Makes a Moat Round £1m Home. The Mirror [online], 7th February. Available at:

www.mirror.co.uk/news/uk-news/floods-stormageddon - englishmans-home-3123425

[accessed 30th June 2014].

Sykes, N. (1953) The English Religious Tradition. London: SCM Press.

Tan, C-B. , Cheung, S. and Hui, Y. (eds) (2001) Tourism, Anthropology and China: Studies in Asian Tourism, no. 1. Bangkok: White Lotus Press.

Taussig, M. (1990) Violence and Resistance in the Americas: The Legacy of Conquest. Journal of Historical Sociology, 3 (3): 209-224.

Taussig, M. (1992) The Nervous System. London: Routledge.

Taylor, P. J. (2001) Which Britain? Which England, Which North? in British Cultural Identities, edited by D. Morley and K. Robbins . Oxford: Oxford University Press, pp. 127-144.

Terry, A. (2013) Gender, Canadian Nationhood and 'Keeping House': The Cultural

Bureaucratisation of Dundurn Castle in Hamilton, Ontario, 1900-1960s. Gender \& History, 25

(1): 47-64.

Thomas, J. (1999) Time, Culture \& Identity: An Interpretive Archaeology. London: Routledge.

Tilley, C. (2009) What Gardens Mean, in Material Culture and Technology in Everyday Life:

Ethnographic Approaches, edited by P. Vannini . New York: Peter Lang, pp. 171-192.

Tilley, C. and Cameron-Daum, K. (2017) An Anthropology of Landscape. London: UCL Press.

Timms, B. and Conway, D. (2012) Slow Tourism at the Caribbean's Geographical Margins.

Tourism Geographies, 14 (3): 396-418.

Trant, J. (2009) Emerging Convergence? Thoughts on Museums, Archives, Libraries, and

Professional Training. Museum Management and Curatorship, 24 (4): 369-387.

Tsintjilonis, D. (2006) Monsters and Cariacatures: Spirit Possession in Tana Toraja. Journal of the Royal Anthropological Institute (NS), 12: 551-567.

Tuan, Y-F. (1977) Space and Place: The Perspective of Experience. Minneapolis: University of Minnesota Press.

Tuan, Y-F. (2005) Architecture, Route to Transcendence, in Architourism, edited by J. Ockman and S. Frausto . Munich: Prestel Publishing, pp. 118-121.

Tucker, H. (2003) Living With Tourism: Negotiating Identities in a Turkish Village. London: Routledge.

Turner, B. S. (1996) The Body and Society: Explorations in Social Theory, 2nd ed. London: Sage.

Turner, B. S. (2008) The Body and Society: Explorations in Social Theory, 3rd ed. London: Sage.

Turner, V. W. (1974) Dramas, Fields and Metaphors: Symbolic Action in Human Society. New York: Cornell University Press.

Turner, V. W. (1978) Encounter With Freud: The Making of a Comparative Symbologist, in The Making of Psychological Anthropology, edited by G. D. Spindler . Berkeley: University of California Press, pp. 558-583.

Turner, V. W. (1982) From Ritual to Theatre: The Human Seriousness of Play. New York: Performing Arts Journal Publication.

Turner, V. W. and Bruner, E. M. (eds) (1986) The Anthropology of Experience. Urbana: University of Illinois Press.

Urban Adventures. (2017) Available at: www.urbanadventures.com/delhi-tour-gandhi-s-delhi [accessed 1st June 2017].

Urry, J. (2000) Sociology Beyond Societies: Mobilities for the Twenty-First Century. London: Routledge.

Urry, J. (2007) Mobilities. Cambridge: Polity Press.

Urry, J. (2009) Aeromobilities and the Global, in Aeromobilities, edited by S. Cwerner, S.

Kesselring and J. Urry . London: Routledge, pp. 25-38.

Vale, L. J. (1992) Architecture, Power, and National Identity. New Haven: Yale University Press. van Uffelen, C. (2012) Airport Architecture. Berlin: Braun. 
Vannini, P. (2012) Ferry Tales: Mobility, Place, and Time on Canada's West Coast. New York: Routledge.

Vannini, P. and Vannini, A. (2016) Wilderness. Abingdon, Oxon: Routledge.

Veijola, S. and Jokinen, E. (1994) The Body in Tourism. Theory, Culture \& Society, 11:

125-151.

Vertovec, S. (2004) Religion and Diaspora, in New Approaches to the Study of Religion:

Volume 2, edited by P. Antes, A. Geertz and R. Warne . Berlin: Walter de Gruyter, pp.

275-304.

Victoria and Albert Museum. (2016) London. Available at:

www.vam.ac.uk/content/exhibitions/disobedient-objects/disobedient-objects-about-the-

exhibition/ [accessed 25th May 2016].

Virilio, P. (1994) Bunker Archaeology, trans. G. Collins . New York: Princeton Architectural

Press.

Visit Berlin. (2017) Available at: www.visitberlin.de/en/checkpoint-charlie [accessed 29th June 2017].

Visit England. (2017) Available at: www.visitengland.com/things-to-

do/heritage\#south\%20east\%20england\&heritage [accessed 1st June 2017].

Wagner, R. (1981) The Invention of Culture, revised and expanded ed. Chicago: University of Chicago Press.

Walsh, K. (1992) The Representation of the Past: Museums and Heritage in the Post-Modern World. London: Routledge.

Wang, N. (1999) Rethinking Authenticity in Tourism Experience. Annals of Tourism Research, 26 (2): 349-370.

Waterson, R. (1997[1990]) The Living House: An Anthropology of Architecture in South-East Asia. London: Thames and Hudson.

Waterton, E. and Watson, S. E. (eds) (2010) Culture, Heritage and Representation:

Perspectives on Visuality and the Past. Farnham: Ashgate.

Wearing, S. , Stevenson, D. and Young, T. (2010) Tourist Cultures: Identity, Place and the

Traveller. London: Sage.

Weiner, A. (1985) Inalienable Wealth. American Ethnologist, 12 (2): 210-227.

Weiner, J. F. (2001) Tree Leaf Talk: A Heideggerian Anthropology. Oxford: Berg.

Weir, A. (2002) Henry VIII: King and Court. London: Pimlico.

Weiss, E. (2010) Establishing Roots at Israel's Ben Gurion Airport Garden: Landscapes of National Identity. National Identities, 12 (2): 199-210.

Wendell, S. (1996) The Rejected Body: Feminist Philosophical Reflections on Disability. New York: Routledge.

White, C. J. (2005) Time and Death: Heidegger's Analysis of Finitude, edited by M. A.

Ralkowski, Forward by H. L. Dreyfus . Aldershot: Ashgate.

Wierzbicka, A. (2008) Why There Are No 'Colour Universals' in Language and Thought. Journal of the Royal Anthropological Society (N.S.), 14 (2): 407-425.

Willerslev, R. (2007) Soul Hunters: Hunting, Animism, and Personhood Among the Siberian Yukaghirs. Berkeley: University of California Press.

Willett, F. (1994) Museums: Two Case Studies of Reaction to Colonialism, in The Politics of the Past, edited by P. Gathercole and D. Lowenthal . London: Routledge, pp. 172-183.

Winter, T. (2007) Post-Conflict Heritage, Postcolonial Tourism: Culture, Politics and

Development at Angkor. Abingdon, Oxon: Routledge.

Winter, T. (2009) Asian Tourism and the Retreat of Anglo-Western Centrism in Tourism Theory. Current Issues in Tourism, 12 (1): 21-31.

Winter, T. , Teo, P. and Chang, T. C. (eds) (2008) Asia on Tour: Exploring the Rise of Asian Tourism. Abingdon, Oxon: Routledge.

Wittgenstein, L. (1980) Culture and Value, 2nd ed, edited by G. H. von Wright, G. and H. Nyman, trans. P. Winch . Oxford: Blackwell.

Wolin, R. (2016[1990]) The Politics of Being: The Political Thought of Martin Heidegger. New York: Columbia University Press.

Woodward, I. (2001) Domestic Objects and the Taste Epiphany: A Resource for Consumption Methodology. Journal of Material Culture, 6: 115-136.

Woodward, I. (2009) Material Culture and Narrative: Fusing Myth, Materiality, and Meaning, in Material Culture and Technology in Everyday Life: Ethnographic Approaches, edited by P. 
Vannini . New York: Peter Lang, pp. 59-72.

Wright, P. (1985) On Living in an Old Country. London: Verso.

Wright, S. , Suchet-Pearson, S. , Lloyd, K. , Burarrwanga, L. L. and Burarrwanga, D. (2009) 'That Means the Fish Are Fat': Sharing Experiences of Animals Through Indigenous-Owned Tourism. Current Issues in Tourism, 12 (5-6): 505-527.

Young, I. M. (1980) Throwing Like a Girl: A Phenomenology of Feminine Body. Comportment Motility and Spatiality. Human Studies, 3 (2): 137-156. 